\title{
New evidence on the oil-democracy nexus utilising the Varieties of Democracy data
}

\author{
Brahim Bergougui ${ }^{\mathrm{a}, \mathrm{b}, *}$, Syed Mansoob Murshed ${ }^{\mathrm{c}, \mathrm{d}}$ \\ ${ }^{\text {a }}$ Research Center in Applied Economics for Development (CREAD), Algiers, Algeria \\ ${ }^{\mathrm{b}}$ National School of Statistics and Applied Economics (ENSSEA), University Pole of Koléa, Algeria \\ ${ }^{c}$ Economics Peace and Conflict, Institute of Social Studies (ISS), Kortenaerkade 12, 2518 AX, The Hague, the Netherlands \\ ${ }^{\mathrm{d}}$ Faculty of Business and Law Coventry University, William Morris Building, Gosford Street, Coventry, CV1 5FB, UK
}

\section{A R T I C L E I N F O}

\section{Keywords:}

Institutional quality

Democratic institutions

Oil dependence

Oil abundance

Political resource curse

\begin{abstract}
A B S T R A C T
This study re-examines the oil and democracy nexus, which is central to the political resource curse by applying the latest democracy dataset, V-DEM, into the analysis in a sample of 100 Developing Countries, over the period 1935-2014. Our study is a contribution to this taxonomic literature where we improve on previous studies not only by employing a novel democratic data source, but also because we use two definitions of oil wealth which renders our results more robust, besides delineating the sample into small and large oil endowments and looking into the experience of two regions, Latin America and the Middle East. Our analysis highlights nuances in the oildemocracy relationship. First, that there is prima facie evidence for a political resource curse if we do not control for pre-existing institutions that promote democracy. Second, once we decompose the sample into small and large oil endowments, the political resource curse vanishes, and also for Latin America, whilst for oil dependent economies in the Middle East and North Africa it still remains. Third, after controlling for pre-existing institutional quality, measured in our case by the rule of law, chances of the political resource curse seem to diminish. We also calculate threshold levels for the quality of the rule of law to be at in society before they turn a curse into a blessing. The converse is equally true, a deterioration in the quality and pervasiveness of the rule of law will cause the political resource curse to reappear, and democratic quality will decline.
\end{abstract}

\section{Introduction}

Does natural-resource wealth foster or hinder democratic institutional outcomes? Notwithstanding decades of research, the question remains unresolved. A growing body of work in both economics and political science has pointed to the 'natural-resource-curse' thesis. ${ }^{1}$ The debate over the resource curse has focused on why resource-rich countries tend to grow at a slower rate and perform more poorly in their economic growth than resource-poor ones (Sachs and Warner 1995).

In recent decades, the resource curse literature has shifted attention to the association between natural-resource wealth (and in particular, oil wealth) and political institutions (democracy). Increasingly oil wealth has come to be viewed as strengthening autocracy, and inhibiting democratic development in developing countries, beginning with the seminal work of Michael Ross $(2001,2015)$. Other researchers, however, have questioned the validity of the empirical regularity of this outcome (Dunning, 2008; Haber and Menaldo, 2011; Herb 2005; O'Connor et al., 2018). Within this group of sceptics, some even find that oil wealth promotes democracy (Brückner et al., 2011; Menaldo 2016; Wacziarg 2012), while others conclude that oil wealth has no significant effect on democracy (Haber and Menaldo 2011; O'Connor et al., 2018). Still others find that the effect that oil wealth has on democracy is conditional on a host of factors (Brooks and Kurtz 2016; Caselli and Tesei 2015; Hendrix 2018; Houle 2018; Masi and Ricciuti 2019) - for example, inequality, institutional strength, failures of authoritarian regimes, the structure of oil-industry ownership and even purely temporal factors (before versus after a structural break, say in 1980 following the second-largest jump in oil prices in 1979.

The literature also reveals a number of gaps and shortcomings that led to ambiguous results - for example, using one single measure of democracy (the majority of prior research has made use of the Polity index as a proxy for democratic institutions), or employing variables

\footnotetext{
* Corresponding author. Research Center in Applied Economics for Development (CREAD), Algiers, Algeria

E-mail addresses: b.bergougi@cread.dz, brahimbergougui@gmail.com (B. Bergougui), murshed@iss.nl, ab2380@coventry.ac.uk (S.M. Murshed).

1 See, among others, Badeeb et al. (2017); Frankel, 2010; Murshed (2018); Ross (2015).
} 
that poorly measure the concept of democracy (Oskarsson and Ottosen 2010). Another shortcoming of the studies was even more glaring: the measurement of oil rents. The data used in most studies measured oil in terms of oil dependence, which caused endogeneity problems (Tsui, 2011). Furthermore, the regression results were weakened by missing data - whether in terms of oil or democracy variables (Lall 2016). The estimations of the impact of natural resources on democracy were based mainly at the cross-sectional level rather than being based on within-country variations (Aslaksen, 2010).

This study engages the aforementioned debate by testing the effects of oil wealth on democratic-institution outcomes over a long-time span beginning in 1935 and ending in 2014. In particular, we examine the relationship between oil and democracy by using a newly released democracy-measuring dataset from the Varieties of Democracy project ${ }^{2}$ - comprising the categories of electoral, liberal, deliberative, participatory and egalitarian democracy -. As far as we know, all previous studies have used either a single measure of democracy (Polity2) or different aspects of democracy - such as political constraints, civil liberties and political rights - to examine the relationship between oil and democracy.

Our paper contributes empirically to the scholarly debate over oil wealth and democracy in three ways:

1) Our study investigates the validity of the 'oil-hinders-democracy' hypothesis. We do this by comparing the effects of both oil abundance - proxied by the quantity of oil and gas extracted in a given year multiplied by the per-unit world price divided by population (oil and gas value per capita), which is a measure of nature's bounty - and oil dependence - proxied by the share of oil and gas value in GDP, which indicates the degree of economic reliance on the oil industry relative to other sectors of the economy- on democratic institutions individually. Most other studies employ only one definition of oil wealth. As the economy diversifies (and grows), we would expect to see a decline in oil-sector dependence. The growing and diversified economy may even decide to conserve its oil stocks, leading to a decline in the oil abundance metric. This may moderate the political resource curse, as the 'rentier' effect has been identified to be central to its working (Ross, 2001). After all, the political resource curse may be more linked to the economy's dependence on this natural resource, particularly in the context of a 'staple' trap (Auty, 2001). Alternatively, democratization or autocratic rule may be related simply to the magnitude of the nature's gift per citizen, which may indicate the degree to which an autocrat can purchase acquiescence from the general public or influential groups. Thus, distinguishing between oil abundance and dependence may be important, as it allows us to better understand the mechanisms leading to the political resource curse. In addition, the relationship between oil endowments and institutional development is fraught with the problem of reverse causality. Oil endowments may worsen institutions, but an excessive reliance on oil revenues to generate national income, oil dependence, can emerge in the presence of poor political institutions and governance mechanisms; see Brunnschweiler and Bulte (2008) and James (2019). We believe that employing System GMM techniques addresses these endogeneity issues in the case of oil dependence. The problem of endogeneity between institutions and oil abundance would be much more limited.

2) To the best of our knowledge, our study is one of the first that has employed a new approach in measuring democracy (i.e. V-DEM dataset) in the resource curse literature. V-DEM dataset has surpassed the most commonly used democracy datasets (i.e. Polity IV

\footnotetext{
${ }^{2}$ Varieties of Democracy (V-DEM) is an international research project which aims to develop new indicators of democracy in all countries all over the world from 1789 to the present.
}

and Freedom House) for multiple reasons can be found in Boese (2019) and Elff and Ziaja (2018). Some of these is that the Polity IV dataset was aimed to capture the de jure institutional framework and Freedom House Index (FHI) created to measure civil liberties and political rights. It is therefore more of a de facto measure. In contrast, $\mathrm{V}$-Dem is placed to a certain degree in between the de facto and de jure institutional framework (Boese, 2019). There are important differences in measurement scale and aggregation procedure that would point to the superiority of V-DEM, including greater variation over time, and its utilization of the distinction between the liberal and electoral components of democracy. Other reason is that V-DEM project was built by numerous of country experts and research assistants from all over the world who have been involved in coding a new dataset that capture distinct features of democracy for almost all countries since 1900. 'Most [experts] have lived in their countries of expertise for nearly thirty years, and at least 60 percent are nationals of that country' (Lindberg et al., 2014, p. 162). In contrast, Polity IV and Freedom House datasets rely on a much smaller number of experts who are mainly citizens of the United States (Elff and Ziaja 2018).

3) Since the effects of oil on democracy may vary in different parts of the world, and for greater in-depth understanding, this study splits its full sample into two classifications: (a) We have selected two regional groups, Middle East and North African (MENA) and Latin America and the Caribbean (LAC); and (b) On another level we divide the full sample into two groups according to their oil endowments, countries with large oil endowments and those with smaller oil endowments, measured in terms of oil wealth per capita. The Middle East has long been regarded as the region with the most entrenched autocracies in the world, Latin America has also followed a different course in its history of democratic development compared to the rest of the developing world (O'Connor et al., 2018). We confine our analysis to developing countries, since developed countries that are oil abundant (such as Norway or the USA) achieved a high level of stable and enduring democratic development well before the advent of oil revenues, and few would suspect the onset of a political resource curse in those countries.

The remainder of the paper is organized as follows: Section 2 outlines the relevant literature review; Section 3 discusses our data and empirical methodology; Section 4 reports on and discusses the main empirical results; Section 5 provides robustness checks; and, finally, conclusions are drawn in Section 6.

\section{Literature review}

Since the end of the twentieth century, the relationship between resource wealth - especially oil wealth - and democratic institutions has received considerable attention. The existing literature on the effects of oil on democracy can be divided into three main branches.

The first, large branch is consistent with the claim that 'oil wealth impedes democracy and makes autocratic states more durable'. For instance, in his path breaking article, Ross (2001) found strong evidence that oil wealth - measured by oil, gas and coal exports as a fraction of Gross Domestic Product (GDP) - delays democratic development and enables authoritarian governments to maintain their rule in a sample of 113 countries. He also was among the first to consider the causal relationship between oil wealth and democracy, and he suggested three mechanisms to explain the adverse effect of oil wealth on democracy:

(a) The 'rentier' effect: oil-rich governments use oil rents to finance public expenditure relative to taxation, thus avoiding democratic accountability;

(b) The 'repression' effect: oil wealth enables governments to rule through strengthening their internal security forces; 
(c) The 'modernization' effect: when oil rents delay modernization as a social force, and with modernization, particularly education, the demand for democracy grows.

Ross re-examined this hypothesis in his later study (Ross 2009) by using a more plausibly exogenous variable of oil wealth measured by oil income per capita - and he finds similar results. His main finding has been strengthened by a number of cross-country studies. Jensen and Wantchekon (2004) find a strong negative correlation between oil dependence and levels of democracy in 46 African states. Smith (2004) uses a different dependent variable by focusing on regime durability instead of the level of democracy. This study examines contrasting claims made by scholars of oil and politics that oil wealth either tends to undermine regime durability or to enhance it. Smith finds that oil wealth is robustly associated with increased regime stability. By using an event-history-analysis approach, Ulfelder (2007) confirms that autocratic governments are typically more durable in resource-rich countries. Tsui (2011) has used a unique dataset that exploits variation in the timing and size of oil discoveries to identify the impact of oil wealth on democracy; his findings are also associated with discovery timing and size. He finds that discovering 100 billion barrels of oil significantly decreases a country's prospects for democratic improvement for three decades. He also finds evidence indicating a greater negative impact of oil discoveries in countries that experienced major finds early in their (post-independence) history than in those countries that did so later. Thus, Tsui offers new evidence for the long-term negative effect of discovering oil wealth on democracy. More recently, Cassidy (2019) has examined the long-run effects of oil wealth on economic and political development outcomes by using information on geological basins to create an instrument for oil production across countries. Based on Instrumental variables estimation for 172 countries from 1966 to 2008, he demonstrates that oil production impedes democracy.

The second branch of the literature (that of the 'Conditionalists') is associated with the claim that 'the effect of oil wealth on democracy is conditional on a host of factors'. Dunning (2008) suggests that natural resources may be associated with either authoritarianism or democracy, and conditioning variables influence whether the relationship between natural resources and democracy is positive or negative. He finds that a positive relationship between natural resources and democracy depends on the level of the private-income-inequality variable, based on a panel dataset that observes Latin America, the world's most unequal region, since 1960. Jones Luong and Weinthal (2010) follow in Dunning's footsteps. They attempt to explain the different political outcomes that have been witnessed in five mineral-rich states of the former Soviet Union (Russia, Azerbaijan, Kazakhstan, Turkmenistan and Uzbekistan), and they conclude that oil wealth only leads to adverse political outcomes when the government has an overriding role in the structure of oil-industry ownership (public or private). Bhavnani and Lupu (2016) show evidence from a natural experiment in Brazil; they argue that the effect of natural-resource revenues on democracy is conditioned by the quality of institutions, and deduce that the greatest adverse effect of oil resources on democratic outcomes is seen when the municipalities of Brazil have weak institutions. Brooks and Kurtz (2016) also put forth a similar conclusion to Bhavnani and Lupu when they re-examine the relationship between oil wealth and political regimes in a panel of 183 countries. They find that oil wealth is not necessarily a curse and may even be a blessing with respect to democratic development. Using data on 118 autocratic countries between 1946 and 2004, Houle (2018) finds that the negative effect of oil on democracy is conditional on the failure of the authoritarian regime in question. In terms of economic-forms theory, Aytac et al. (2016) have offered a new explanation for the conditional effects of the resource curse by distinguishing between two kinds of economies: contract-intensive and clientelist economies. Using a two-step robust System GMM estimator for 150 countries from 1973 to 2000 , their results indicate that the negative effect of natural-resource dependence on democracy is conditional on the prevailing norm governing interactions between economic agents. Specifically, resource dependence is detrimental for democracy only in nations with clientelist or patronage based economies while the resource curse is avoided in nations with contract-intensive economies. Caselli and Tesei (2015) find that resource-rent windfalls, which typically occur during commodity-price booms, encourage authoritarianism, as measured by the Polity scale, in countries that are already autocracies - prompting them to move towards greater levels of autocracy, and all the more so when the country displayed a relatively low initial degree of autocracy, as it provides more resources for dictators. Resource-rent windfalls have little impact on countries that are already democracies in this connection. The findings are robust to a variety of techniques, including GMM techniques, as well as commodity classifications.

The third branch of the literature is consistent with the claim that 'oil wealth does not always impede democracy'. In other words, the second branch did not, in its view, find consistent support for the claim that 'oil wealth impedes democracy'. Herb (2005) has examined the claim that oil impedes democracy, which was addressed by Ross (2001). He finds weak support for the notion that there is a net negative effect of oil wealth on democracy. In their important study, which has had a powerful impact on the 'oil-hinders-democracy' debate, Haber and Menaldo (2011) have questioned the conventional wisdom that oil fuels authoritarianism. Their study tests whether there is a long-term relationship between oil wealth and the level of democracy within countries over time. Using a unique historical dataset on resource wealth that covers up to 168 countries from 1800 to 2006 and applying time-series-centric methods that control for country-fixed effects and operationalize explicitly specified counterfactuals, they find that the association between oil wealth and authoritarianism disappears over the long run, and generate results that suggest a resource blessing. Using a similar approach, Liou and Musgrave (2013) apply a synthetic controls method in a small set of countries, and they find little evidence that a resource curse systematically prevents democratization. O'Connor et al. (2018) re-evaluate Haber and Menaldo's findings; the results that they end up with lead back to Haber and Menaldo's conclusion. By analysing the effect of oil on democracy in the context of colonization experiences, Omgba (2015) examines a large sample of oil-producing countries, and his main findings are that contemporaneous levels of democracy in oil countries are positively associated with the time elapsed between the beginning of oil production and a country's political independence. In general, this branch casts doubt on the existence of a straightforward political resource curse.

Consequently, the literature is inconclusive and, therefore, the present study aims to fill the research gap by testing the following research hypotheses:

Hypothesis 1. The effect of oil wealth on democratic institutions differs across geographic regions (i.e., LAC and MENA regions) and depends on the level of oil endowments (i.e., high and low oil endowment).

Hypothesis 2. The effect of oil wealth on democratic institutions can be conditioned by institutional quality (i.e., rule of law).

\section{Data and the empirical model}

\subsection{Data}

\subsubsection{Sample}

The study examines the relationship between two measures of oil wealth and five measures of democracy. The panel data for this study is strongly balanced and it includes 100 developing countries for the 1935-2014 period (based on a five-year moving average) ${ }^{3}$ in the full sample, but we also separate Latin America and the Caribbean (LAC), as

\footnotetext{
${ }^{3}$ Our choice of the period (1935-2014) is limited by the availability of the data on oil wealth from Ross and Mahdavi (2015) dataset.
} 
well as Middle Eastern and North African (MENA) countries from the full sample. Supplementary Table S1 provides a list of countries in each group.

\subsubsection{Variables}

3.1.2.1. Data on oil wealth. The most commonly used measure in empirical studies on the resource curse is resource dependence, which reflects the degree to which a country's economy relies on the resource sector (Haber and Menaldo 2011; Ross 2001; Wiens et al., 2014). Other studies use a measure of resource abundance, which measures endowment (Al-Ubaydli 2012; Ramsay 2011). However, we distinguish our study from much of previous empirical work by employing two measures of oil wealth (oil abundance and oil dependence) rather than one. This will give us a unique insight into the conditions under which natural resources may block or encourage democracy.

We also utilize another division of oil abundance into high and low oil endowment types. Following Cotet and Tsui (2013), we calculate the median of average oil value per capita over the full sample period 1935-2014 (i.e. the log of oil value per capita is 3.84), and then we define the 3.84 value as the threshold level to determine whether an oil country has large or small oil endowment. Thus, we divide our sample into two groups: small-scale oil endowment and large-scale oil endowment countries based on the 3.84 value as a threshold. More precisely, a dummy variable takes a value of one if the country produces more than 3.84 , and it takes a value of zero, otherwise.

The data on oil and gas value is obtained from the dataset of Ross and Mahdavi (2015) , ${ }^{4}$ who obtained data from the US Geological Survey, the US Energy Information Administration, the World Bank and the BP Statistical Review. This dataset provides the best available information about the volume and value of oil and natural-gas production in all countries from 1935 to 2014.

Due to the highly skewed nature of the data on resource rents and to the presence of zero values in the 'log' transformation of oil wealth, we enter our regressions in the form of natural $\log$ of ( $1+$ oil wealth). A detailed description is provided in Table S3.

3.1.2.2. Data on democracy. Researchers typically use the Polity index as a proxy for democratic institutions (Haber and Menaldo 2011; Herb 2005; Tsui 2011), which has several shortcomings as a measurement of democracy in terms of political rights and liberties - as identified by Oskarsson and Ottosen (2010). One of these is that Polity does not consider to what extent the citizenry enjoys civil liberties and political rights, focusing mainly on the nature of multi-party electoral processes. Fortunately, since 2010, more than 50 scholars have responded with a global collaborative effort, known as the Varieties of Democracy (V-DEM) dataset, to stringently document the features of democracy for 201 countries from 1789 to 2017 . To test our hypothesis, we draw our dependent variables from this unique database (V-DEM, Version 9). In this study we used five main indicators of democracy that offer distinctive approaches to defining democracy (Coppedge et al., 2015): Electoral, Liberal, Deliberative, Participatory and Egalitarian democracy. It is important to note that each democracy index is based on various subcomponents. Supplementary Table S2 A summarizes the definitions of the five-outcome variables as defined by V-DEM. All of these democracy measures are reported in such a way that assigns values between 0 and 1 . Larger values indicate a better quality of democracy. V-DEM data shows much greater variation and has the advantage of a variety of sub-components which are fine grained to capture more aspects of democracy. In particular, it separates a liberal component index from the electoral democracy index. While elections are common in

\footnotetext{
4 - https://dataverse.harvard.edu/dataset.xhtml?persistentId=doi :10.7910/DVN/ZTPWOY (Ross and Mahdavi, 2015).
}

most developing countries respect for liberal values are less common.

3.1.2.3. Other variables. In order to avoid any potential omitted variable bias, we include other explanatory variables in our core regression that have been defined in the literature and are strongly associated with democratic institutional development: income per capita (Bolt and van Zanden, 2014), the log of population (Bolt and van Zanden, 2014) and institutional quality. Following Acemoglu et al. (2001) and Alexeev and Conrad (2009), we mainly use the rule of law to proxy institutional quality, as it is an important brake on the abuse of power and is believed to be important in promoting good quality economic institutions.

Supplementary Table S3 describes all the variables used in our empirical analysis.

\subsection{The empirical model}

We now investigate the effects of oil abundance and oil dependence on within-country democratic institutional outcomes. We regress the five democracy measures on the two indicators of oil wealth and a series of other covariates over the period 1935-2014 in a global sample of 100 developing countries and to reduce the risk of endogeneity, all explanatory variables enter the regressions with a five-year lag. Specifically, we estimate the following two models:

$$
\begin{aligned}
\mathrm{D}_{\mathrm{it}} & =A_{1} \quad \mathrm{D}_{\mathrm{i}, \mathrm{t}-1}+A_{2}(\text { Oil Abundance })_{\mathrm{i}, \mathrm{t}-1}+A_{3}(\mathrm{GDP} \mathrm{pc})_{\mathrm{i}, \mathrm{t}-1} \\
& +A_{4}(\text { Population })_{\mathrm{i}, \mathrm{t}-1}+\delta_{\mathrm{i}}+\omega_{t}+\mu_{\mathrm{i}, \mathrm{t}} \\
\mathrm{D}_{\mathrm{it}} & =B_{1} \quad \mathrm{D}_{\mathrm{i}, \mathrm{t}-1}+B_{2}(\text { Oil Dependence })_{\mathrm{i}, \mathrm{t}-1}+B_{3}(\mathrm{GDP} \mathrm{pc})_{\mathrm{i}, \mathrm{t}-1} \\
& +B_{4}(\text { Population })_{\mathrm{i}, \mathrm{t}-1}+\gamma_{\mathrm{i}}+\partial_{t}+\varepsilon_{\mathrm{i}, \mathrm{t}}
\end{aligned}
$$

Where $\mathrm{D}_{\mathrm{i}, \mathrm{t}}$ denotes one of the democracy measures (Electoral, Liberal, Deliberative, Participatory or Egalitarian) for country i at period t. The main variable of interest in Eq. (1) is oil abundance (the log of oil value per capita) and in Eq. (2) is Oil Dependence (the oil value as share of GDP). $A_{2}$ in Eq. (1) therefore captures the effect of oil abundance on each democracy measure and $B_{2}$ in Eq. (2) therefore captures the effect of oil dependence on each democracy measure. $\delta_{\mathrm{i}}$ and $\gamma_{\mathrm{i}}$ denote country-fixed effects that capture unobservable time-invariant country characteristics. $\omega_{t}$ and $\partial_{t}$ are time-fixed effects that capture common shocks to democracy for all countries. The error terms $\mu_{i t}$ and $\varepsilon_{\text {it }}$ capture all other omitted factors and are clustered at the country level -hence, they may be arbitrarily serially correlated within countries.

In order to cope with the several problems including endogeneity problem, unobserved heterogeneity, autocorrelation, and the dependent variable persistence (Aytac et al., 2016; Brooks and Kurtz 2016), we use the GMM technique (Arellano and Bover, 1995). Pooled ordinary least squares in a dynamic model of panel data is biased and inconsistent. Furthermore, GMM is more efficient than two-stage least squares (2SLS) regression because it accounts for heteroscedasticity (Hall, 2007). GMM estimators come in two variants: the difference GMM estimators and the System GMM estimators. We use the System GMM estimator because it is more robust in gauging efficiency gains and reducing finite sample bias. Moreover, in all System GMM analyses, we use two-step System GMM estimator and apply Windmeijer correction (Windmeijer, 2005), due to lower bias and standard errors. It is also more efficient than the one-step System GMM estimator because it is more robust to the problem of weak instruments.

As GMM estimators of Arellano and Bover are typically designed for panel data sets with large $\mathrm{N}$ and small $\mathrm{T}$ (Mitze 2012), we take the average over five-year intervals (Aslaksen, 2010) in the 1935-2014 panel (where if $t_{1}=1935-39$, then $t_{2}=1940-44$ etc.). Now as the number of periods ( $t$ ) in our study is seventeen 5 -year intervals, System GMM estimator is justifiable because it relies on $\mathrm{N}>\mathrm{T}$. We therefore conduct two statistical tests to check the consistency of our System GMM estimator. First, Arrelano-Bond test for serial correlation. Second, the 

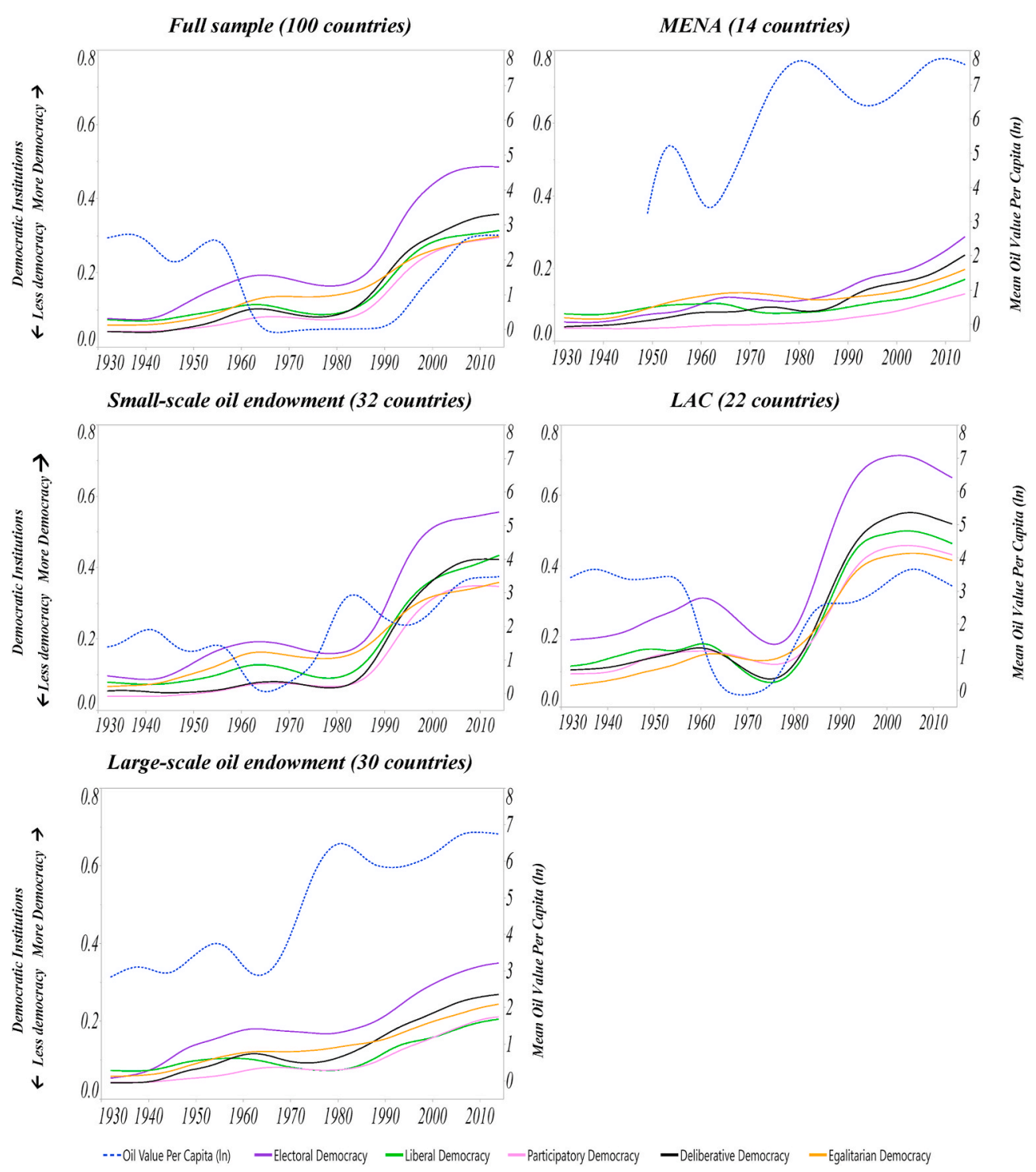

Fig. 1. Oil Abundance (Oil value per capita) \& the five Democratic Institutions measures. Smoothed trends (1935-2014). Source: Authors' construction using data from V-Dem (2019) and Ross and Mahdavi (2015).

Hansen test for instrument validity (over-identification restrictions).

\section{Empirical results}

\subsection{General summary statistics}

Appendix Table A1 shows the summary statistics for the variables used in the analysis and for the full sample, and for each group individually. Column 1 reports the mean and standard deviation for the whole sample. In the next two columns, the full sample is classified into two groups according to the scale of oil endowment (as measured by oil and gas value per capita). In the last three columns, countries are classified into the two aforementioned regional groups. Panel A of Table A1 presents the key independent variables: oil value per capita and oil value as a share of GDP. Panel B provides descriptive statistics for the five dependent variables of democracy. Panel $C$ shows the other variables. Panel A indicates that MENA countries are characterized by a greater oil abundance - oil value per capita- and oil dependence - oil value as share of GDP- than those of other regions. MENA countries tended to be richer and depend more on oil. Panel B shows that the average of five democracy variables improves over time. Remarkably, Panel B demonstrates that small-scale oil endowed countries are associated with a higher mean score in all the democracy indices than the large-scale oil endowed countries. Also, it shows that the LAC countries have achieved the highest mean score in all the democracy indices. Interestingly, in Panel C the LAC countries also have the greatest mean score in rule of law.

Figs 1 and 2 demonstrate how the trends of the five democracy measures and the two indicators of oil wealth (oil value per capita and oil value as a share of GDP) have evolved over the 1935-2014 period across the full sample of 100 countries, and in each of the country groups. It appears that oil value per capita began to decrease gradually from the 1980s until the mid-to late 1990s when it switches back to an increasing trend.

Moreover, the five democracy measures have generally increased over time in all the country groups - with a noticeable surge from the 1990 s onwards. In addition, electoral democracy shows the greatest improvement compared with the remaining four democracy measures, while participatory democracy has the lowest score in most sub-sample groups.

\subsection{System GMM estimation results}

We now begin our empirical investigation of the democratic effects 

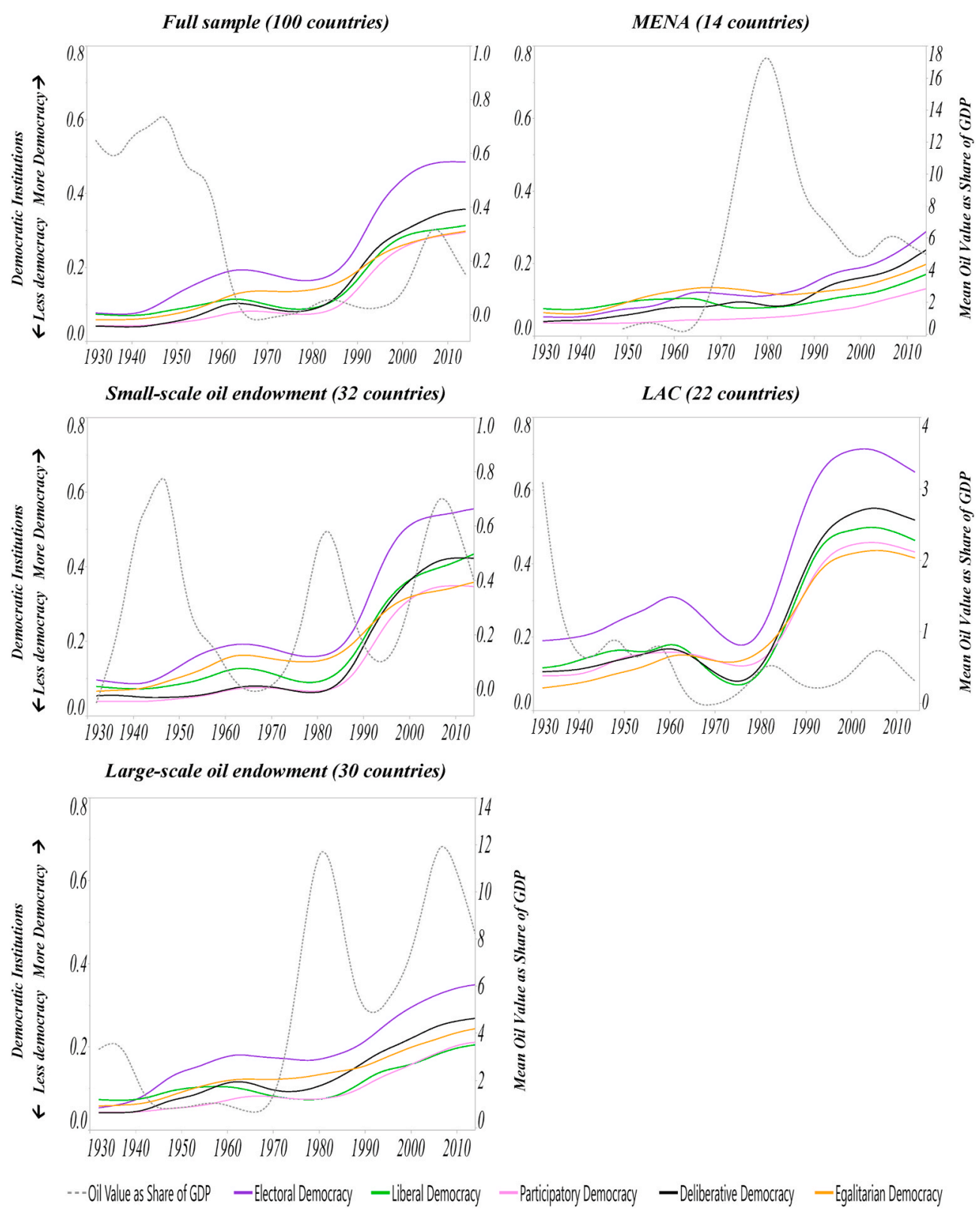

Fig. 2. Oil Dependence \& the five Democratic Institutions measures. Smoothed trends (1935-2014). Source: Authors' construction using data from V-Dem (2019) and Ross and Mahdavi (2015).

of oil abundance and oil dependence. Table (1-5) present the main System GMM estimation results. In each table, we categorize the analysis per type of oil wealth (abundance/dependence) measure to compare their effects on each of the five democratic-institution measures.

\subsubsection{Effect of oil wealth on democracy in the full sample}

Table 1 presents the effects of oil abundance and oil dependence on each of the five democracy measures in the full sample. The results presented in Column 1-5 of Panel A provide strong evidence that oil abundance hampers democracy over time for the full sample. but with one exception - the liberal democracy was insignificant, even though, the sign remains negative. According to System GMM estimates shown in Column 1 of Table 1, a $1 \%$ increase in oil value per capita reduces the level of electoral democracy by $0.004 \%$. In Columns $2-5$ of panel A, the same increase in oil value per capita reduces the level of deliberative democracy by $0.003 \%$, participatory democracy by $0.005 \%$ and egalitarian democracy by $0.002 \%$. This trend applies also to oil dependence as well (Panel B, Column 1-5).
This provides prima facie evidence that oil abundance and oil dependence impede democracy in the full sample. This result is consistent with Andersen and Ross (2013), Cassidy (2019), Fails (2019), Hendrix (2018), Ross (2001) and Wigley (2018).

\subsubsection{Conditional effect of oil wealth on democracy: Oil abundance context}

Table 2 reports System GMM estimates for the two measures of oil wealth in small-scale oil endowed countries. According to System GMM estimates (Panel A, Column 1-5), oil abundance does not have any significant effect on five democracy measures, and this applies also to oil dependence (Panel B, Column 1-5).

Table 3 presents the effects of oil abundance and oil dependence on each of the five democracy measures in large-scale oil endowed countries. Unlike small-scale oil countries, oil abundance does have a positive and significant effect on electoral democracy in large-scale oil producers (Panel A, Column 1) while it does not have any significant effect on the rest of the democracy measures. This result is similar to those obtained 
Table 1

The effect of oil wealth on each of the five democratic-institution measures in full Sample: Oil Abundance vs Oil Dependence. Five-year panel 1935-2014.

\begin{tabular}{|c|c|c|c|c|c|}
\hline \multirow{3}{*}{ Dependent Variables } & \multicolumn{5}{|c|}{ Panel (A). Oil Abundance (Oil Value per capita) and Democracy } \\
\hline & Electoral Democracy & Liberal Democracy & Deliberative Democracy & Participatory Democracy & Egalitarian Democracy \\
\hline & (1) & $(2)$ & (3) & (4) & (5) \\
\hline Oil Abundance (t-1) & $\begin{array}{l}-0.004 * \\
(0.002)\end{array}$ & $\begin{array}{l}-0.003 \\
(0.003)\end{array}$ & $\begin{array}{l}-0.003^{* * *} \\
(0.001)\end{array}$ & $\begin{array}{l}-0.005^{* *} \\
(0.002)\end{array}$ & $\begin{array}{l}-0.002 * \\
(0.001)\end{array}$ \\
\hline GDP per capita (t-1) & $\begin{array}{l}0.012 * \\
(0.006)\end{array}$ & $\begin{array}{l}0.012 \\
(0.010)\end{array}$ & $\begin{array}{l}0.010^{* *} \\
(0.005)\end{array}$ & $\begin{array}{l}0.014^{* *} \\
(0.006)\end{array}$ & $\begin{array}{l}0.010 * * \\
(0.005)\end{array}$ \\
\hline Population (t-1) & $\begin{array}{l}0.006^{* * *} \\
(0.002)\end{array}$ & $\begin{array}{l}0.007^{*} \\
(0.004)\end{array}$ & $\begin{array}{l}0.004 * * * \\
(0.001)\end{array}$ & $\begin{array}{l}0.005^{* * *} \\
(0.002)\end{array}$ & $\begin{array}{l}0.003^{*} \\
(0.001)\end{array}$ \\
\hline Observations & 784 & 784 & 784 & 784 & 784 \\
\hline No. of countries & 100 & 100 & 100 & 100 & 100 \\
\hline Hansen J: P-value & 0.998 & 0.998 & 0.997 & 0.997 & 0.999 \\
\hline AR (2): P-value & 0.114 & 0.714 & 0.177 & 0.302 & 0.0718 \\
\hline \multirow[t]{2}{*}{ Dependent Variables } & \multicolumn{5}{|c|}{ Panel (B). Oil Dependence (Oil Value as a share of GDP) and Democracy } \\
\hline & $\begin{array}{l}\text { Electoral Democracy } \\
\text { (1) }\end{array}$ & $\begin{array}{l}\text { Liberal Democracy } \\
\text { (2) }\end{array}$ & $\begin{array}{l}\text { Deliberative Democracy } \\
\text { (3) }\end{array}$ & $\begin{array}{l}\text { Participatory Democracy } \\
\text { (4) }\end{array}$ & $\begin{array}{l}\text { Egalitarian Democracy } \\
\text { (5) }\end{array}$ \\
\hline Oil Dependence (t-1) & $\begin{array}{l}-0.013^{*} \\
(0.007)\end{array}$ & $\begin{array}{l}-0.019^{* * *} \\
(0.010)\end{array}$ & $\begin{array}{l}-0.010^{* *} \\
(0.004)\end{array}$ & $\begin{array}{l}-0.013^{* * *} \\
(0.006)\end{array}$ & $\begin{array}{l}-0.008^{* *} \\
(0.004)\end{array}$ \\
\hline GDP per capita (t-1) & $\begin{array}{l}0.004 \\
(0.005)\end{array}$ & $\begin{array}{l}0.011 \\
(0.007)\end{array}$ & $\begin{array}{l}0.006 \\
(0.004)\end{array}$ & $\begin{array}{l}0.006 \\
(0.005)\end{array}$ & $\begin{array}{l}0.006 \\
(0.004)\end{array}$ \\
\hline Population (t-1) & $\begin{array}{l}0.003 \\
(0.003)\end{array}$ & $\begin{array}{l}0.002 \\
(0.005)\end{array}$ & $\begin{array}{l}0.002 \\
(0.003)\end{array}$ & $\begin{array}{l}0.003 \\
(0.003)\end{array}$ & $\begin{array}{l}0.001 \\
(0.002)\end{array}$ \\
\hline Observations & 763 & 763 & 763 & 763 & 763 \\
\hline No. of countries & 100 & 100 & 100 & 100 & 100 \\
\hline Hansen J: P-value & 0.996 & 0.997 & 0.999 & 0.991 & 0.996 \\
\hline AR (2): P-value & 0.111 & 0.759 & 0.158 & 0.301 & 0.0635 \\
\hline
\end{tabular}

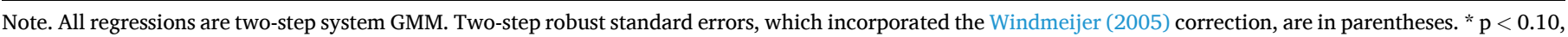
$* * \mathrm{p}<0.05,{ }^{* *} \mathrm{p}<0.01$. AR (2) = Arrelano-Bond test for second-order serial correlation. Hansen test $=$ Test of instrument over-identification restrictions.

Table 2

The effect of oil wealth on each of the five democratic-institution measures in small oil countries: Oil Abundance vs Oil Dependence. Five-year panel $1935-2014$.

\begin{tabular}{|c|c|c|c|c|c|}
\hline \multirow{3}{*}{ Dependent Variables } & \multicolumn{5}{|c|}{ Panel (A). Oil Abundance (Oil Value per capita) and Democracy } \\
\hline & Electoral Democracy & Liberal Democracy & Deliberative Democracy & Participatory Democracy & Egalitarian Democracy \\
\hline & (1) & (2) & (3) & (4) & (5) \\
\hline Oil Abundance (t-1) & $\begin{array}{l}-0.003 \\
(0.004)\end{array}$ & $\begin{array}{l}-0.008 \\
(0.006)\end{array}$ & $\begin{array}{l}-0.002 \\
(0.002)\end{array}$ & $\begin{array}{l}-0.003 \\
(0.019)\end{array}$ & $\begin{array}{l}-0.003 \\
(0.002)\end{array}$ \\
\hline GDP per capita (t-1) & $\begin{array}{l}0.009 \\
(0.009)\end{array}$ & $\begin{array}{l}0.018 \\
(0.013)\end{array}$ & $\begin{array}{l}0.009 \\
(0.008)\end{array}$ & $\begin{array}{l}0.012 \\
(0.023)\end{array}$ & $\begin{array}{l}0.017 \\
(0.018)\end{array}$ \\
\hline Population (t-1) & $\begin{array}{l}0.002 \\
(0.003)\end{array}$ & $\begin{array}{l}0.011 * * \\
(0.005)\end{array}$ & $\begin{array}{l}0.004 * * \\
(0.002)\end{array}$ & $\begin{array}{l}0.003 \\
(0.024)\end{array}$ & $\begin{array}{l}0.003 \\
(0.003)\end{array}$ \\
\hline Observations & 353 & 353 & 353 & 353 & 353 \\
\hline No. of countries & 32 & 32 & 32 & 32 & 32 \\
\hline Hansen J: P-value & 0.127 & 0.538 & 0.117 & 0.130 & 1 \\
\hline AR (2): P-value & 0.325 & 0.249 & 0.785 & 0.918 & 0.480 \\
\hline \multirow[t]{3}{*}{ Dependent Variables } & \multicolumn{5}{|c|}{ Panel (B). Oil Dependence (Oil Value as a share of GDP) and Democracy } \\
\hline & Electoral Democracy & Liberal Democracy & Deliberative Democracy & Participatory Democracy & Egalitarian Democracy \\
\hline & (1) & $(2)$ & (3) & (4) & (5) \\
\hline Oil Dependence (t-1) & $\begin{array}{l}-0.005 \\
(0.006)\end{array}$ & $\begin{array}{l}-0.000 \\
(0.022)\end{array}$ & $\begin{array}{l}0.029 \\
(0.024)\end{array}$ & $\begin{array}{l}-0.002 \\
(0.027)\end{array}$ & $\begin{array}{l}-0.002 \\
(0.002)\end{array}$ \\
\hline GDP per capita (t-1) & $\begin{array}{l}0.020 \\
(0.047)\end{array}$ & $\begin{array}{l}0.024 \\
(0.027)\end{array}$ & $\begin{array}{l}0.004 \\
(0.018)\end{array}$ & $\begin{array}{l}0.005 \\
(0.020)\end{array}$ & $\begin{array}{l}0.004 \\
(0.007)\end{array}$ \\
\hline Population (t-1) & $\begin{array}{l}0.003 \\
(0.009)\end{array}$ & $\begin{array}{l}0.022 \\
(0.045)\end{array}$ & $\begin{array}{l}0.116 \\
(0.076)\end{array}$ & $\begin{array}{l}0.004 \\
(0.011)\end{array}$ & $\begin{array}{l}-0.000 \\
(0.004)\end{array}$ \\
\hline Observations & 350 & 350 & 350 & 350 & 350 \\
\hline No. of countries & 32 & 32 & 32 & 32 & 32 \\
\hline Hansen J: P-value & 1 & 1 & 1 & 1 & 0.126 \\
\hline AR (2): P-value & 0.622 & 0.737 & 0.355 & 0.957 & 0.0759 \\
\hline
\end{tabular}

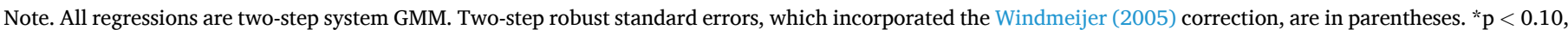
${ }^{* * \mathrm{p}}<0.05, * * * \mathrm{p}<0.01$. AR $(2)=$ Arrelano-Bond test for second-order serial correlation. Hansen test $=$ Test of instrument over-identification restrictions.

by Brückner et al., 2011, Liou and Musgrave 2013, Menaldo (2016) and Wacziarg (2012) who found a convincing evidence that oil wealth is good for democracy. For the other measure of oil wealth (oil dependence), there is no significant relationship with the five measures of democracy (Panel B, Column 1-5).

The estimates from Table 2 indicate that oil abundance and oil 
Table 3

The effect of oil wealth on each of the five democratic-institution measures in large oil countries: Oil Abundance vs Oil Dependence. Five-year panel $1935-2014$.

\begin{tabular}{|c|c|c|c|c|c|}
\hline \multirow{3}{*}{ Dependent Variables } & \multicolumn{5}{|c|}{ Panel (A). Oil Abundance (Oil Value per capita) and Democracy } \\
\hline & Electoral Democracy & Liberal Democracy & Deliberative Democracy & Participatory Democracy & Egalitarian Democracy \\
\hline & (1) & $(2)$ & (3) & (4) & (5) \\
\hline Oil Abundance (t-1) & $\begin{array}{l}0.038^{*} \\
(0.021)\end{array}$ & $\begin{array}{l}0.005 \\
(0.006)\end{array}$ & $\begin{array}{l}0.011 \\
(0.024)\end{array}$ & $\begin{array}{l}-0.014 \\
(0.018)\end{array}$ & $\begin{array}{l}0.001 \\
(0.001)\end{array}$ \\
\hline GDP per capita (t-1) & $\begin{array}{l}-0.107 \\
(0.078)\end{array}$ & $\begin{array}{l}-0.007 \\
(0.015)\end{array}$ & $\begin{array}{l}-0.029 \\
(0.068)\end{array}$ & $\begin{array}{l}0.037 \\
(0.047)\end{array}$ & $\begin{array}{l}0.002 \\
(0.004)\end{array}$ \\
\hline Population (t-1) & $\begin{array}{l}0.023^{* * *} \\
(0.011)\end{array}$ & $\begin{array}{l}-0.001 \\
(0.005)\end{array}$ & $\begin{array}{l}0.007 \\
(0.009)\end{array}$ & $\begin{array}{l}-0.001 \\
(0.007)\end{array}$ & $\begin{array}{l}0.003^{*} \\
(0.002)\end{array}$ \\
\hline Observations & 373 & 373 & 373 & 373 & 373 \\
\hline No. of countries & 30 & 30 & 30 & 30 & 30 \\
\hline Hansen J: P-value & 1 & 1 & 1 & 1 & 0.578 \\
\hline AR (2): P-value & 0.484 & 0.238 & 0.834 & 0.346 & 0.427 \\
\hline \multirow[t]{2}{*}{ Dependent Variables } & \multicolumn{5}{|c|}{ Panel (B). Oil Dependence (Oil Value as a share of GDP) and Democracy } \\
\hline & $\begin{array}{l}\text { Electoral Democracy } \\
\text { (1) }\end{array}$ & $\begin{array}{l}\text { Liberal Democracy } \\
\text { (2) }\end{array}$ & $\begin{array}{l}\text { Deliberative Democracy } \\
\text { (3) }\end{array}$ & $\begin{array}{l}\text { Participatory Democracy } \\
\text { (4) }\end{array}$ & $\begin{array}{l}\text { Egalitarian Democracy } \\
\text { (5) }\end{array}$ \\
\hline Oil Dependence (t-1) & $\begin{array}{l}-0.0075 \\
(0.0079)\end{array}$ & $\begin{array}{l}-0.011 \\
(0.012)\end{array}$ & $\begin{array}{l}-0.003 \\
(0.004)\end{array}$ & $\begin{array}{l}-0.004 \\
(0.004)\end{array}$ & $\begin{array}{l}-0.004 \\
(0.003)\end{array}$ \\
\hline GDP per capita (t-1) & $\begin{array}{l}0.0001 \\
(0.0068)\end{array}$ & $\begin{array}{l}0.003 \\
(0.016)\end{array}$ & $\begin{array}{l}0.003 \\
(0.003)\end{array}$ & $\begin{array}{l}0.003 \\
(0.005)\end{array}$ & $\begin{array}{l}0.008 \\
(0.006)\end{array}$ \\
\hline Population (t-1) & $\begin{array}{l}0.0038 \\
(0.0031)\end{array}$ & $\begin{array}{l}-0.001 \\
(0.005)\end{array}$ & $\begin{array}{l}0.002 \\
(0.002)\end{array}$ & $\begin{array}{l}0.003 \\
(0.002)\end{array}$ & $\begin{array}{l}0.003 \\
(0.002)\end{array}$ \\
\hline Observations & 357 & 1 & 357 & 357 & 357 \\
\hline No. of countries & 30 & 0.115 & 30 & 30 & 30 \\
\hline Hansen J: P-value & 0.713 & -0.011 & 1 & 1 & 1 \\
\hline AR (2): P-value & 0.213 & $(0.012)$ & 0.0835 & 0.144 & 0.360 \\
\hline
\end{tabular}

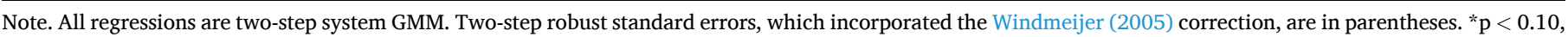
$* * \mathrm{p}<0.05,{ }^{* *} \mathrm{p}<0.01$. AR (2) = Arrelano-Bond test for second-order serial correlation. Hansen test $=$ Test of instrument over-identification restrictions.

Table 4

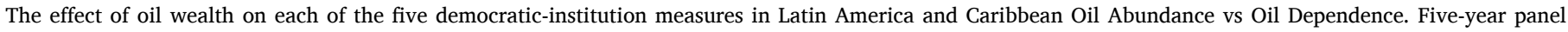
1935-2014.

\begin{tabular}{|c|c|c|c|c|c|}
\hline \multirow{3}{*}{ Dependent Variables } & \multicolumn{5}{|c|}{ Panel (A). Oil Abundance (Oil Value per capita) and Democracy } \\
\hline & Electoral Democracy & Liberal Democracy & Deliberative Democracy & Participatory Democracy & Egalitarian Democracy \\
\hline & (1) & (2) & (3) & (4) & (5) \\
\hline Oil Abundance (t-1) & $\begin{array}{l}-0.036 \\
(0.024)\end{array}$ & $\begin{array}{l}-0.016 \\
(0.083)\end{array}$ & $\begin{array}{l}-0.008 \\
(0.010)\end{array}$ & $\begin{array}{l}-0.003 \\
(0.007)\end{array}$ & $\begin{array}{l}-0.001 \\
(0.003)\end{array}$ \\
\hline GDP per capita (t-1) & $\begin{array}{l}0.263 \\
(0.188)\end{array}$ & $\begin{array}{l}0.117 \\
(0.591)\end{array}$ & $\begin{array}{l}0.075 \\
(0.072)\end{array}$ & $\begin{array}{l}0.023 \\
(0.042)\end{array}$ & $\begin{array}{l}0.026 \\
(0.023)\end{array}$ \\
\hline Population (t-1) & $\begin{array}{l}0.103 \\
(0.069)\end{array}$ & $\begin{array}{l}0.040 \\
(0.174)\end{array}$ & $\begin{array}{l}0.023 \\
(0.024)\end{array}$ & $\begin{array}{l}0.009 \\
(0.012)\end{array}$ & $\begin{array}{l}0.003 \\
(0.004)\end{array}$ \\
\hline Observations & 268 & 268 & 202 & 268 & 268 \\
\hline No. of countries & 22 & 22 & 22 & 22 & 22 \\
\hline Hansen J: P-value & 0.998 & 0.988 & 1 & 0.990 & 0.997 \\
\hline AR (2): P-value & 0.424 & 0.396 & 0.360 & 0.821 & 0.252 \\
\hline \multirow[t]{2}{*}{ Dependent Variables } & \multicolumn{5}{|c|}{ Panel (B). Oil Dependence (Oil Value as a share of GDP) and Democracy } \\
\hline & $\begin{array}{l}\text { Electoral Democracy } \\
\text { (1) }\end{array}$ & $\begin{array}{l}\text { Liberal Democracy } \\
\text { (2) }\end{array}$ & $\begin{array}{l}\text { Deliberative Democracy } \\
\text { (3) }\end{array}$ & $\begin{array}{l}\text { Participatory Democracy } \\
\text { (4) }\end{array}$ & $\begin{array}{l}\text { Egalitarian Democracy } \\
\text { (5) }\end{array}$ \\
\hline Oil Dependence (t-1) & $\begin{array}{l}0.045 \\
(0.462)\end{array}$ & $\begin{array}{l}-0.977 \\
(1.380)\end{array}$ & $\begin{array}{l}0.164 \\
(0.379)\end{array}$ & $\begin{array}{l}0.179 \\
(0.310)\end{array}$ & $\begin{array}{l}-0.038 \\
(1.124)\end{array}$ \\
\hline GDP per capita (t-1) & $\begin{array}{l}0.005 \\
(0.254)\end{array}$ & $\begin{array}{l}1.415^{* * *} \\
(0.054)\end{array}$ & $\begin{array}{l}-0.214 \\
(0.386)\end{array}$ & $\begin{array}{l}-0.102 \\
(0.223)\end{array}$ & $\begin{array}{l}0.039 \\
(0.847)\end{array}$ \\
\hline Population (t-1) & $\begin{array}{l}0.475 \\
(0.652)\end{array}$ & $\begin{array}{l}-1.158 \\
(1.729)\end{array}$ & $\begin{array}{l}-0.003 \\
(0.047)\end{array}$ & $\begin{array}{l}0.085 \\
(0.112)\end{array}$ & $\begin{array}{l}0.005 \\
(0.093)\end{array}$ \\
\hline Observations & 264 & 264 & 264 & 264 & 264 \\
\hline No. of countries & 22 & 22 & 22 & 22 & 22 \\
\hline Hansen J: P-value & 1 & 1 & 1 & 1 & 0.689 \\
\hline AR (2): P-value & 0.515 & 0.378 & 0.723 & 0.0576 & 0.200 \\
\hline
\end{tabular}

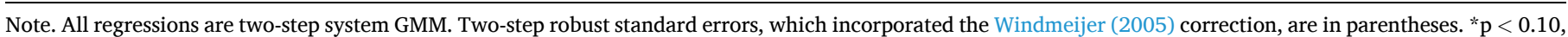
${ }^{* *} \mathrm{p}<0.05, * * * \mathrm{p}<0.01$. AR(2) = Arrelano-Bond test for second-order serial correlation. Hansen test $=$ Test of instrument over-identification restrictions.

dependence have no effect on electoral, liberal, deliberative, participatory, or egalitarian democracy during the period 1935-2014 for smallscale oil endowed countries. This empirical finding supports the view put forward by Haber and Menaldo (2011), who suggest that natural resources and democracy are unrelated.

Moreover, after confirming that oil wealth adversely affects 
Table 5

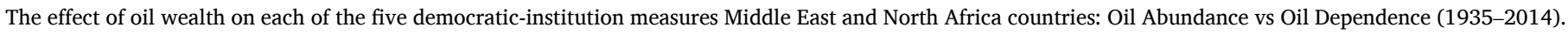
Five-years average.

\begin{tabular}{|c|c|c|c|c|c|}
\hline \multirow{3}{*}{ Dependent Variables } & \multicolumn{5}{|c|}{ Panel (A). Oil Abundance (Oil Value per capita) and Democracy } \\
\hline & Electoral Democracy & Liberal Democracy & Deliberative Democracy & Participatory Democracy & Egalitarian Democracy \\
\hline & (1) & $(2)$ & (3) & (4) & (5) \\
\hline Oil Abundance (t-1) & $\begin{array}{l}-0.041 \\
(0.035)\end{array}$ & $\begin{array}{l}-0.021 \\
(0.017)\end{array}$ & $\begin{array}{l}-0.030 \\
(0.025)\end{array}$ & $\begin{array}{l}-0.029 \\
(0.021)\end{array}$ & $\begin{array}{l}-0.039 \\
(0.035)\end{array}$ \\
\hline GDP per capita (t-1) & $\begin{array}{l}0.040 \\
(0.036)\end{array}$ & $\begin{array}{l}0.024 \\
(0.021)\end{array}$ & $\begin{array}{l}0.024 \\
(0.023)\end{array}$ & $\begin{array}{l}-0.010 \\
(0.045)\end{array}$ & $\begin{array}{l}0.068 \\
(0.062)\end{array}$ \\
\hline Population (t-1) & $\begin{array}{l}0.017 \\
(0.011)\end{array}$ & $\begin{array}{l}0.015 \\
(0.011)\end{array}$ & $\begin{array}{l}0.003^{* *} \\
(0.001)\end{array}$ & $\begin{array}{l}-0.020 \\
(0.046)\end{array}$ & $\begin{array}{l}0.008 \\
(0.007)\end{array}$ \\
\hline Observations & 156 & 156 & 156 & 156 & 156 \\
\hline No. of countries & 14 & 14 & 14 & 14 & 14 \\
\hline Hansen J: P-value & 1 & 1 & 1 & 1 & 1 \\
\hline AR (2): P-value & 0.390 & 0.751 & 0.400 & 0.544 & 0.401 \\
\hline \multirow[t]{2}{*}{ Dependent Variables } & \multicolumn{5}{|c|}{ Panel (B). Oil Dependence (Oil Value as a share of GDP) and Democracy } \\
\hline & $\begin{array}{l}\text { Electoral Democracy } \\
\text { (1) }\end{array}$ & $\begin{array}{l}\text { Liberal Democracy } \\
(2)\end{array}$ & $\begin{array}{l}\text { Deliberative Democracy } \\
\text { (3) }\end{array}$ & $\begin{array}{l}\text { Participatory Democracy } \\
\text { (4) }\end{array}$ & $\begin{array}{l}\text { Egalitarian Democracy } \\
\text { (5) }\end{array}$ \\
\hline Oil Dependence (t-1) & $\begin{array}{l}-1.590 * \\
(0.942)\end{array}$ & $\begin{array}{l}-0.433^{* * *} \\
(0.077)\end{array}$ & $\begin{array}{l}-0.317^{* * *} \\
(0.087)\end{array}$ & $\begin{array}{l}-0.492^{* k *} \\
(0.118)\end{array}$ & $\begin{array}{l}-0.212^{* * *} \\
(0.044)\end{array}$ \\
\hline GDP per capita (t-1) & $\begin{array}{l}0.140 * \\
(0.084)\end{array}$ & $\begin{array}{l}0.069 * * * \\
(0.008)\end{array}$ & $\begin{array}{l}-0.178 \\
(0.153)\end{array}$ & $\begin{array}{l}-0.183 \\
(0.149)\end{array}$ & $\begin{array}{l}0.025^{* * *} \\
(0.009)\end{array}$ \\
\hline Population (t-1) & $\begin{array}{l}-0.044 \\
(0.027)\end{array}$ & $\begin{array}{l}-0.006 \\
(0.004)\end{array}$ & $\begin{array}{l}-0.056 \\
(0.041)\end{array}$ & $\begin{array}{l}-0.064 \\
(0.042)\end{array}$ & $\begin{array}{l}-0.012^{* * *} \\
(0.004)\end{array}$ \\
\hline Observations & 148 & 148 & 148 & 148 & 148 \\
\hline No. of countries & 14 & 14 & 14 & 14 & 14 \\
\hline Hansen J: P-value & 1 & 1 & 1 & 1 & 1 \\
\hline AR (2): P-value & 0.282 & 0.716 & 0.694 & 0.671 & 0.112 \\
\hline
\end{tabular}

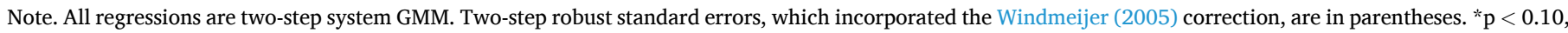
$* * \mathrm{p}<0.05, * * * \mathrm{p}<0.01$. AR $(2)=$ Arrelano-Bond test for second-order serial correlation. Hansen test $=$ Test of instrument over-identification restrictions.

democracy across the full sample of developing countries (Table 1), it seems that this negative effect vanishes when we classify developing countries into small and large oil endowed countries. We consistently find a positive relationship between "oil abundance" and electoral democracy in large oil producers, while there is no significant relationship in small oil endowed countries. Thus, oil's effect on democracy depends on whether the nation has a large or small oil endowment. Furthermore, the estimation results also clearly imply that the effect of oil on democracy in large-scale oil producers differs along the definition of the scale of oil wealth.

\subsubsection{Conditional effect of oil wealth on democracy: Regional context}

To investigate whether geographic location is important in understanding the oil-democracy relationship, we break the full sample into two regional groups, Latin America and the Caribbean (LAC) and Middle East and North Africa (MENA), and present the results in Tables 4 and 5. The System GMM estimates reveal that the effect of oil wealth on democracy in the two regional groups depends on the type of oil wealth (abundance/dependence) measures.

First, unlike for the full sample, oil abundance does not have any significant effects on each of the five democracy measures for Middle East and North Africa and Latin America and the Caribbean (Panel A of Tables 4 and 5). This is in line with existing empirical studies such as O'Connor et al. (2018), who find similar results and suggest that oil abundance has no effect on democracy in Middle East and North Africa. Second, when we measure oil wealth in term of oil dependence (oil value as a share of GDP) for LAC countries (Table 4, Panel B) oil dependence does not have any significant effect on the five democracy measures.

For MENA countries (Table 5, Panel B), we find that oil dependence has a negative effect on each of the five democracy measures. This suggests that oil dependence hinders democracy in MENA countries. These results are consistent with Andersen and Aslaksen (2013), Aslaksen (2010), Murshed (2018), Ross (2001), Jensen and Wantchekon (2004) and Anyanwu and Erhijakpor, 2014.
Moreover, the insignificant oil-democracy relationship in LAC countries are unexpected, since oil wealth in Latin America has traditionally been considered a blessing in several studies (Ahmadov 2013; Dunning 2008; Menaldo 2016). One possible explanation for this unexpected result is an indirect effect of oil wealth on democracy through institutional quality, which points to the need to re-estimate the relationship by including the interaction term in Equations (1) and (2) identified above.

4.2.4. Conditional effect of oil wealth on democracy: Institutional context Next, we investigate whether the relationship between oil wealth and democracy is conditional on institutional quality (H2). Nations with strong institutions are supposed to have an advantage to benefit from oil wealth, whereas countries with weak institutions are subjected to the political resource curse (Dunning 2008; Jensen and Wantchekon 2004). According to Dunning (2008), the influence of oil wealth on democracy can be both direct and indirect. To crystallize the indirect effects of oil abundance and oil dependence on democracy via institutional quality, the more powerful approach that has been used in primary studies is by including an interaction term between the quality of institutions and oil wealth. We use the rule of law as our choice for an indicator of institutional quality, as it serves as a check on autocracy and promotes the development of good quality economic institutions. Accordingly, the new estimation models are:

$$
\begin{aligned}
\mathrm{D}_{\mathrm{it}} & =\mathrm{A}_{1} \quad \mathrm{D}_{\mathrm{i}, \mathrm{t}-1}+\mathrm{A}_{2}(\text { Oil Abundance })_{\mathrm{i}, \mathrm{t}-1}+\mathrm{A}_{3}(\text { Institutional Quality })_{\mathrm{i}, \mathrm{t}-1} \\
& +\mathrm{A}_{4}(\text { Oil Abundance*Institutional Quality })_{\mathrm{i}, \mathrm{t}-1}+\mathrm{A}_{5}(\mathrm{GDP} \mathrm{pc})_{\mathrm{i}, \mathrm{t}-1} \\
& +\mathrm{A}_{6}(\text { Population })_{\mathrm{i}, \mathrm{t}-1}+\delta_{\mathrm{i}}+\omega_{\mathrm{t}}+\mu_{\mathrm{i}, \mathrm{t}}
\end{aligned}
$$




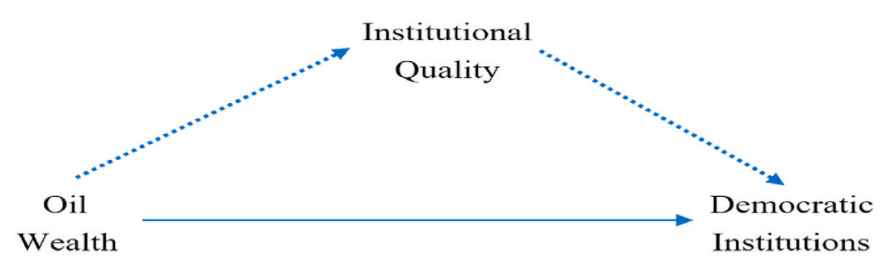

Fig. 3. Oil wealth and democratic institutions: Direct and Indirect Links. Source: Authors. Solid arrow $=$ direct link; dashed arrow $=$ indirect link.

$$
\begin{aligned}
\mathrm{D}_{\mathrm{it}} & =\mathrm{B}_{1} \quad \mathrm{D}_{\mathrm{i}, \mathrm{t}-1}+\mathrm{B}_{2}(\text { Oil Dependence })_{\mathrm{i}, \mathrm{t}-1}+\mathrm{B}_{3}(\text { Institutional Quality })_{\mathrm{i}, \mathrm{t}-1} \\
& +\mathrm{B}_{4}\left(\text { Oil Dependence }{ }^{*} \text { Institutional Quality }\right)_{\mathrm{i}, \mathrm{t}-1}+\mathrm{B}_{5}(\mathrm{GDP} \mathrm{pc})_{\mathrm{i}, \mathrm{t}-1} \\
& +\mathrm{B}_{6}(\text { Population })_{\mathrm{i}, \mathrm{t}-1}+\gamma_{\mathrm{i}}+\partial_{\mathrm{t}}+\varepsilon_{\mathrm{i}, \mathrm{t}}
\end{aligned}
$$

Where rule of law is a proxy to institutional quality, $A_{3}$ captures the effect of the interaction between oil abundance and institutional quality on democracy, and $B_{3}$ captures the effect of the interaction between oil dependence and institutional quality on democracy. Fig. 3 describes in graphical form the direct and indirect effects (via the institutionalstrength channel) of oil wealth on the democratic institutions; these effects are represented by solid and dashed arrows.

Tables 6 and 7, report the estimates of the effects of the oil-institutional quality interaction on each of the five democracy measures based on the System GMM estimator for oil abundance and dependence respectively. The results of the conditional effect turn out to be fairly impressive. For the full sample and the four country groups, we observe a switch in sign, as the negative effect of oil wealth becomes positive when we interact it with institutional quality.

Estimates for the System GMM models report that, when considering oil abundance, the interaction effects of oil wealth and institutional quality are positive for the full sample (Table 6, Panel A), small-scale oil endowment (Table 6, Panel B), large-scale oil endowment (Table 6, Panel C), LAC (Table 6, Panel D) and MENA countries (Table 6, Panel E). Turning to oil dependence as a measure of oil wealth, results for the system GMM also suggest a positive and significant effect for the full sample and the four country groups (Table 7) for almost all of the specifications.

This indicates that institutional quality in form of rule of law

\begin{tabular}{|c|c|c|c|c|c|}
\hline \multirow[t]{2}{*}{ Dependent Variables } & \multirow{2}{*}{$\frac{\text { Electoral Democracy }}{(1)}$} & \multirow{2}{*}{$\frac{\text { Liberal Democracy }}{(2)}$} & \multirow{2}{*}{$\frac{\text { Deliberative Democracy }}{(3)}$} & \multirow{2}{*}{$\frac{\text { Participatory Democracy }}{(4)}$} & \multirow{2}{*}{$\frac{\text { Egalitarian Democracy }}{(5)}$} \\
\hline & & & & & \\
\hline \multicolumn{6}{|l|}{ Panel A. Full sample (100 countries) } \\
\hline \multirow[t]{2}{*}{ Institutional Quality (t-1) } & $0.081 * * *$ & $0.047^{*}$ & $0.037 * * *$ & $0.056 * * *$ & $0.034 * * *$ \\
\hline & $(0.019)$ & $(0.026)$ & $(0.013)$ & $(0.019)$ & $(0.012)$ \\
\hline \multirow[t]{2}{*}{ Oil Abundance t-1 } & $-0.006^{* * *}$ & $-0.007^{* *}$ & $-0.004 * * *$ & $-0.006^{* * *}$ & $-0.008^{* * *}$ \\
\hline & $(0.002)$ & $(0.003)$ & $(0.001)$ & $(0.002)$ & $(0.001)$ \\
\hline \multirow[t]{2}{*}{ (Oil Abundance $\times$ Institutional Quality) t-1 } & $0.008^{* *}$ & 0.006 & 0.004 & 0.005 & $0.010 * * *$ \\
\hline & $(0.004)$ & $(0.008)$ & $(0.002)$ & $(0.004)$ & $(0.002)$ \\
\hline Hansen J: P-value & 1 & 1 & 1 & 1 & 1 \\
\hline AR (2): P-value & 0.904 & 0.0791 & 0.0765 & 0.482 & 0.0564 \\
\hline \multicolumn{6}{|c|}{ Panel B. Small-scale Oil Endowment (32 countries) } \\
\hline \multirow[t]{2}{*}{ Institutional Quality (t-1) } & $0.196^{* * *}$ & 0.085 & $0.066^{* *}$ & $0.253^{* * *}$ & $0.200^{* * *}$ \\
\hline & $(0.067)$ & $(0.078)$ & $(0.027)$ & $(0.063)$ & $(0.056)$ \\
\hline \multirow[t]{2}{*}{ Oil Abundance t-1 } & $-0.026^{* *}$ & -0.025 & $-0.015^{* *}$ & -0.019 & $-0.023^{* *}$ \\
\hline & $(0.012)$ & $(0.017)$ & $(0.007)$ & $(0.012)$ & $(0.009)$ \\
\hline \multirow{2}{*}{ (Oil Abundance $\times$ Institutional Quality) t- 1} & $0.041^{* *}$ & 0.023 & $0.023^{*}$ & 0.029 & $0.043^{* * *}$ \\
\hline & $(0.020)$ & $(0.029)$ & $(0.012)$ & $(0.022)$ & $(0.016)$ \\
\hline Hansen J: P-value & 0.338 & 0.428 & 0.574 & 0.661 & 0.638 \\
\hline AR (2): P-value & 0.305 & 0.697 & 0.751 & 0.143 & 0.280 \\
\hline \multicolumn{6}{|c|}{ Panel C. Large-scale Oil Endowment (30 countries) } \\
\hline \multirow[t]{2}{*}{ Institutional Quality (t-1) } & $-0.421^{* *}$ & -0.241 & $-0.166^{* * *}$ & 0.050 & $-0.140 * * *$ \\
\hline & $(0.174)$ & $(0.224)$ & $(0.056)$ & $(0.124)$ & $(0.044)$ \\
\hline \multirow[t]{2}{*}{ Oil Abundance t-1 } & -0.004 & -0.015 & -0.003 & -0.007 & -0.002 \\
\hline & $(0.009)$ & $(0.019)$ & $(0.003)$ & $(0.005)$ & $(0.003)$ \\
\hline \multirow[t]{2}{*}{ (Oil Abundance $\times$ Institutional Quality) t-1 } & $0.071^{* *}$ & $0.088^{* *}$ & $0.026 * * *$ & $0.041^{* *}$ & $0.024 * * *$ \\
\hline & $(0.034)$ & $(0.045)$ & $(0.008)$ & $(0.019)$ & $(0.008)$ \\
\hline Hansen J: P-value & 1 & 0.0313 & 0.998 & 0.242 & 1 \\
\hline AR (2): P-value & 0.274 & 0.657 & 0.0869 & 0.196 & 0.583 \\
\hline \multicolumn{6}{|c|}{ Panel D. Latin America and Caribbean ( 22 countries) } \\
\hline \multirow[t]{2}{*}{ Institutional Quality (t-1) } & -0.174 & $-2.895^{* *}$ & -0.124 & $-0.806^{* *}$ & -0.767 \\
\hline & $(0.157)$ & $(1.140)$ & $(0.114)$ & $(0.349)$ & $(0.551)$ \\
\hline \multirow[t]{2}{*}{ Oil Abundance t-1 } & $-0.124 * *$ & $-0.510 * *$ & $-0.080 *$ & $-0.242^{* *}$ & $-0.447 * *$ \\
\hline & $(0.053)$ & $(0.226)$ & $(0.043)$ & $(0.101)$ & $(0.213)$ \\
\hline \multirow[t]{2}{*}{ (Oil Abundance $\times$ Institutional Quality) t-1 } & $0.206^{* *}$ & $0.371 *$ & $0.162^{* *}$ & $0.558^{* *}$ & $0.634 * *$ \\
\hline & $(0.086)$ & $(0.193)$ & $(0.080)$ & $(0.232)$ & $(0.309)$ \\
\hline Hansen J: P-value & 0.991 & 1 & 0.923 & 1 & 1 \\
\hline AR (2): P-value & 0.235 & 0.120 & 0.965 & 0.246 & 0.0940 \\
\hline \multicolumn{6}{|c|}{ Panel E. Middle East and North Africa (14 countries) } \\
\hline Institutional Quality (t-1) & $-0.693^{*}$ & $-0.339 * * *$ & $-0.145^{* *}$ & -0.313 & 0.127 \\
\hline & $(0.381)$ & $(0.096)$ & $(0.065)$ & $(0.231)$ & $(0.115)$ \\
\hline Oil Abundance t-1 & $-0.100^{*}$ & $-0.015^{* * *}$ & $-0.011^{* *}$ & $-0.050^{*}$ & -0.001 \\
\hline & $(0.052)$ & $(0.006)$ & $(0.005)$ & $(0.028)$ & $(0.014)$ \\
\hline (Oil Abundance $\times$ Institutional Quality) t-1 & $0.205^{* *}$ & 0.030 & $0.024 * *$ & 0.080 & -0.015 \\
\hline & $(0.089)$ & $(0.021)$ & $(0.010)$ & $(0.052)$ & $(0.025)$ \\
\hline Hansen J: P-value & 1 & 0.150 & 0.874 & 1 & 1 \\
\hline AR (2): P-value & 0.857 & 0.380 & 0.224 & 0.408 & 0.410 \\
\hline
\end{tabular}

Table 6

The effect of oil abundance-institutional quality interaction on each of the five democratic-institution measures. Five-year panel $1935-2014$.

Note. All regressions are two-step system GMM. Two-step robust standard errors, which incorporated the Windmeijer (2005) correction, are in parentheses. * $\mathrm{p}<0.10$, ${ }^{* *} \mathrm{p}<0.05,{ }^{* * *} \mathrm{p}<0.01$. AR(2) = Arrelano-Bond test for second-order serial correlation. Hansen test $=$ Test of instrument over-identification restrictions. 
Table 7

The effect of oil dependence-institutional quality interaction on each of the five democratic-institution measures. Five-year panel $1935-2014$.

\begin{tabular}{|c|c|c|c|c|c|}
\hline \multirow[t]{2}{*}{ Dependent Variables } & \multirow{2}{*}{$\frac{\text { Electoral }}{\text { Democracy }}$} & \multirow{2}{*}{$\frac{\text { Liberal }}{\text { Democracy }}$} & \multirow{2}{*}{$\frac{\text { Deliberative }}{\text { Democracy }}$} & \multirow{2}{*}{$\frac{\text { Participatory }}{\text { Democracy }}$} & \multirow{2}{*}{$\frac{\text { Egalitarian }}{\text { Democracy }}$} \\
\hline & & & & & \\
\hline & (1) & (2) & (3) & (4) & (5) \\
\hline \multicolumn{6}{|l|}{ Panel A. Full sample (100 countries) } \\
\hline \multirow[t]{2}{*}{ Institutional Quality (t-1) } & $0.258^{* * *}$ & $0.048^{*}$ & $0.036^{* *}$ & 0.010 & 0.008 \\
\hline & $(0.008)$ & $(0.027)$ & $(0.016)$ & $(0.013)$ & $(0.013)$ \\
\hline \multirow[t]{2}{*}{ Oil Dependence t-1 } & $-0.002^{*}$ & $-0.041 * * *$ & $-0.021^{* * *}$ & $-0.021^{* * *}$ & $-0.010^{* *}$ \\
\hline & $(0.001)$ & $(0.009)$ & $(0.003)$ & $(0.004)$ & $(0.005)$ \\
\hline \multirow[t]{2}{*}{ (Oil dependence $\times$ Institutional Quality) t- 1} & $0.039^{* * * *}$ & $0.094^{* * * *}$ & $0.058^{* * *}$ & $0.039^{* * *}$ & $0.039^{* * *}$ \\
\hline & $(0.004)$ & $(0.024)$ & $(0.008)$ & $(0.012)$ & $(0.012)$ \\
\hline Hansen J: P-value & 1 & 1 & 1 & 1 & 1 \\
\hline AR (2): P-value & 0.123 & 0.204 & 0.140 & 0.102 & 0.0559 \\
\hline \multicolumn{6}{|c|}{ Panel B. Small-scale Oil Endowment (32 countries) } \\
\hline \multirow[t]{2}{*}{ Institutional Quality (t-1) } & $0.851^{* * *}$ & 0.092 & 0.278 & $0.226^{* * *}$ & $0.128^{*}$ \\
\hline & $(0.171)$ & $(0.071)$ & $(0.204)$ & $(0.060)$ & $(0.067)$ \\
\hline \multirow[t]{2}{*}{ Oil Dependence t-1 } & $-0.269 * * *$ & $-0.068 * * *$ & -0.082 & -0.067 & -0.016 \\
\hline & $(0.104)$ & $(0.026)$ & $(0.062)$ & $(0.067)$ & $(0.074)$ \\
\hline \multirow[t]{2}{*}{ (Oil dependence $\times$ Institutional Quality) t-1 } & $0.827 * * *$ & $0.160^{* *}$ & 0.337 & 0.186 & 0.069 \\
\hline & $(0.296)$ & $(0.075)$ & $(0.262)$ & $(0.181)$ & $(0.182)$ \\
\hline Hansen J: P-value & 32 & 32 & 32 & 32 & 32 \\
\hline AR (2): P-value & 0.146 & 1 & 1 & 0.275 & 1 \\
\hline \multicolumn{6}{|c|}{ Panel C. Large-scale Oil Endowment (30 countries) } \\
\hline \multirow[t]{2}{*}{ Institutional Quality (t-1) } & $0.441 * *$ & -0.075 & 0.014 & -0.069 & -0.064 \\
\hline & $(0.207)$ & $(0.106)$ & $(0.072)$ & $(0.058)$ & $(0.068)$ \\
\hline \multirow[t]{2}{*}{ Oil Dependence t-1 } & $-0.129 *$ & 0.006 & -0.021 & $-0.067 * *$ & -0.034 \\
\hline & $(0.071)$ & $(0.070)$ & $(0.048)$ & $(0.033)$ & $(0.030)$ \\
\hline \multirow[t]{2}{*}{ (Oil dependence $\times$ Institutional Quality) t-1 } & $0.726^{* * *}$ & -0.265 & 0.055 & $0.251 *$ & 0.204 \\
\hline & $(0.271)$ & $(0.392)$ & $(0.279)$ & $(0.140)$ & $(0.167)$ \\
\hline Hansen J: P-value & 0.763 & 1 & 1 & 1 & 1 \\
\hline & 0.124 & 0.145 & 0.467 & 0.0841 & 0.192 \\
\hline \multicolumn{6}{|c|}{ Panel D. Latin America and Caribbean ( 22 countries) } \\
\hline \multirow[t]{2}{*}{ Institutional Quality (t-1) } & 0.486 & -0.650 & -0.149 & 0.103 & $0.843^{* * *}$ \\
\hline & $(0.817)$ & $(1.849)$ & $(0.868)$ & $(0.292)$ & $(0.251)$ \\
\hline \multirow[t]{2}{*}{ Oil Dependence t-1 } & $-1.686^{* *}$ & $-0.910 * * *$ & $-1.607^{*}$ & $-1.710^{* *}$ & 0.015 \\
\hline & $(0.778)$ & $(0.337)$ & $(0.857)$ & $(0.691)$ & $(0.075)$ \\
\hline \multirow[t]{2}{*}{ (Oil dependence $\times$ Institutional Quality) $t-1$} & $2.654 *$ & $2.184^{*}$ & $1.829 *$ & $2.938^{* *}$ & $0.259 *$ \\
\hline & $(1.470)$ & (1.117) & $(0.998)$ & $(1.218)$ & $(0.144)$ \\
\hline Hansen J: P-value & 1 & 1 & 1 & 1 & 1 \\
\hline AR (2): P-value & 0.144 & 0.243 & 0.104 & 0.0697 & 0.365 \\
\hline Panel E. Middle East and North Africa (14 & & & & & \\
\hline Institutional Quality (t-1) & $-0.065^{* *}$ & 0.071 & -0.044 & 0.043 & $-0.062^{* *}$ \\
\hline & $(0.029)$ & $(0.170)$ & $(0.043)$ & $(0.047)$ & $(0.024)$ \\
\hline Oil Dependence t-1 & $-0.056^{*}$ & -0.313 & -0.020 & -0.020 & $-0.040 * *$ \\
\hline & $(0.032)$ & $(0.225)$ & $(0.031)$ & $(0.022)$ & $(0.018)$ \\
\hline (Oil dependence $\times$ Institutional Quality) $t-1$ & $0.430 * *$ & 0.141 & 0.011 & 0.141 & $0.205^{* *}$ \\
\hline & $(0.212)$ & $(0.729)$ & $(0.162)$ & $(0.110)$ & $(0.103)$ \\
\hline Hansen J: P-value & 1 & 1 & 0.814 & 0.802 & 1 \\
\hline AR (2): P-value & 0.365 & 0.775 & 0.245 & 0.380 & 0.402 \\
\hline
\end{tabular}

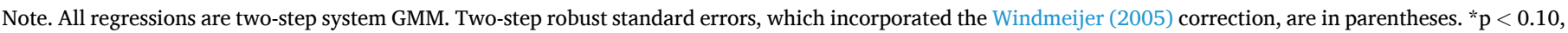
${ }^{* * \mathrm{p}}<0.05, * * * \mathrm{p}<0.01$. AR $(2)=$ Arrelano-Bond test for second-order serial correlation. Hansen test $=$ Test of instrument over-identification restrictions.

mitigates the negative relationship between oil wealth and democracy, and it serves to halt the resource curse of an oil endowment. It also suggests the vital role of institutional quality when it comes to designing policy to enhance oil wealth management and its effect on democracy.

The results support the claim that the effect of oil abundance and oil dependence on democracy is conditional on the quality of institutions. This finding is in conformity with Dunning's (2008) argument, who posits that the effect of oil on democracy is conditional on levels of income inequality, and those of Bhavnani and Lupu (2016) and Mehlum et al. (2006), for whom the significant factor is the quality of institutions. Jensen and Wantchekon (2004) also argue that resource-rich countries can become democratic only if they choose to strengthen their institutions of accountability within the state. Moreover, this outcome implies that oil abundance and oil dependence promote democracy in indirect ways through strong institutions.

Nevertheless, to get a better understanding of how a country's level of institutional quality mediates the effect of oil wealth on democratic institutions, we compute the conditional marginal effects (CME) of oil wealth on democracy by differentiating Eq. (3) and Eq. (4) as follows:

$$
\begin{aligned}
& C M E_{i, t}^{(\text {oil abund })}=\frac{\partial \text { democracy }}{\partial \text { oil abund }}=\widehat{A}_{\text {oil abund }}+\widehat{A}_{4}(\text { Institutional Quality })_{i, t-1} \\
& C M E_{i, t}^{(\text {oil depend })}=\frac{\partial \text { democracy }}{\partial \text { oil depend }}=\widehat{B}_{\text {oil depend }}+\widehat{B}_{4}(\text { Institutional Quality })_{i, t-1}
\end{aligned}
$$

Eq. (5) represents the conditional marginal effect of oil abundance on democracy in Eq. (3), Whilst Eq. (6) represents the conditional marginal effect of oil dependence on democracy in Eq. (4). Figs. (4a) -(4e) present the estimated conditional marginal effects (solid line) of oil abundance on democracy for varying levels of institutional quality that correspond to Column 1 of Table 6. Figs. (5a) -(5e) illustrate the conditional marginal effects (solid line) of oil dependence on democracy at each level of institutional quality that correspond to Column 1 of Table 7 . The dashed red lines around the marginal effects line represent 90 percent confidence intervals and calculated using the Esarey and Sumner's (2017) procedure.

All marginal effects plots consistently demonstrate the significant 

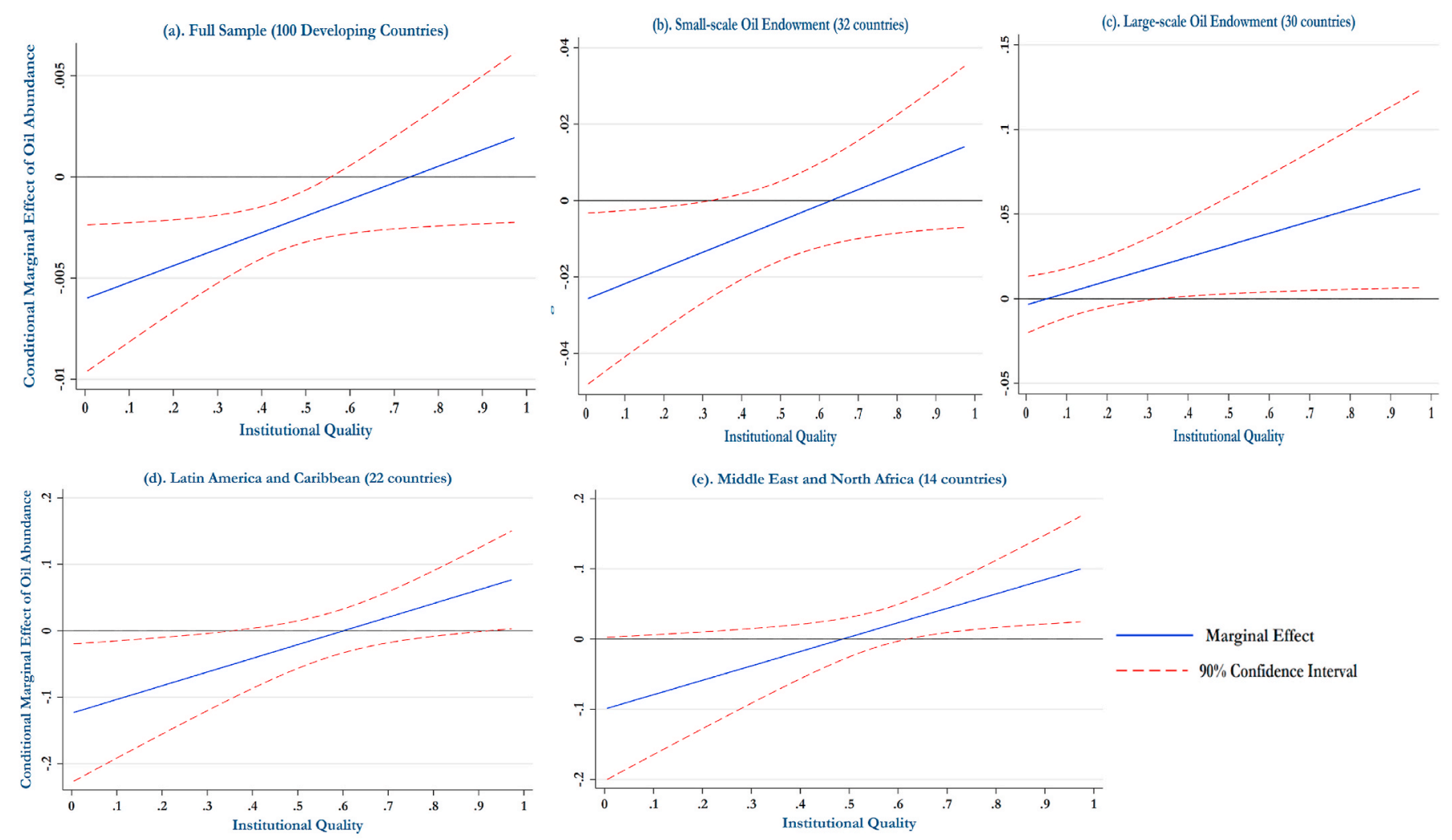

Note: Data are marginal effects based on the System GMM regression presented in Column 1 of Table 6 . The 90 percent confidence intervals around the estimates are calculated using the Esarey and Sumner's (2017) procedure.

Fig. 4. Conditional marginal effect of oil abundance on electoral democracy at different levels of institutional quality (CMEoil abundance)

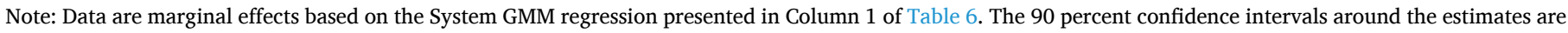
calculated using the Esarey and Sumner's (2017) procedure.

moderating effect of institutional quality, which serve to increase electoral democracy as oil endowment increases. With higher levels of institutional quality, the positive contribution of oil abundance and dependence to electoral democracy increase in magnitude.

In Fig. 4, the final effect of oil abundance on electoral democracy depends on the quality of institutions in full sample and in each of the four country groups. The contribution of oil abundance on electoral democracy becomes positive only when countries reach a certain threshold level of institutional quality, higher than about 0.57 for analysis of full sample (Fig. 4 (a)), higher than about 0.35 for the analysis of small oil endowment (Fig. 4(b)), higher than about 0.38 for the analysis of large oil endowment (Fig. 4(c)), higher than about 0.39 for analysis of LAC (Fig. 4(d)), higher than about 0.62 for analysis of MENA countries (Fig. 4(e)). Countries with an institutional quality of less than these values, show a negative association between oil abundance and electoral democracy.

Similarly, Fig. 5 illustrates that, when we consider oil dependence, the marginal effect of oil dependence on electoral democracy in full sample and in each of the country groups is negative at low values of institutional quality, but when institutional quality surpasses roughly the values of 0.32 in Fig. 4 (a), 0.29 in Fig. 4 (b), 0.3 in Fig. 4 (c), 0.37 in Fig. 4 (d), and 0.49 in Fig. 4 (e) respectively for the full sample, smallscale oil endowment, large-scale oil endowment, LAC and MENA countries. We begin to see positive marginal effects of rising oil dependence on electoral democracy. MENA countries have the highest institutional quality threshold levels before oil stops being a curse, hence the resource curse is more acute in that region as hypothesized by us earlier.

In that regard, we would like to highlight some important points. Overall, when we consider the full sample of developing countries, we find a robust evidence supporting oil hinders-democracy hypothesis for the both of oil wealth (abundance/dependence) measure. Our results provide strong evidence for the conditionality of the political resource curse 'conditionalists view'. Hence, this paper's findings provide evidence to reassure that oil abundance does not hinder democracy and can even be a blessing rather than a curse under the conditionalist view. However, a part of our findings diverges from the studies of Anderson and Ross 2014; Ahmadov (2013); Aslaksen (2010); Houle (2018); Jensen and Wantchekon (2004); Ross (2001, 2009) and Goldberg et al. (2008), which claim that increased oil abundance retards democracy. This inconsistency may be attributed to the use of the new V-DEM dataset, which was not employed in any of these studies.

\section{Further robustness checks}

In this section we report on several exercises to ensure the robustness of our baseline results, we have made several changes - as follows:

$\checkmark$ The substitution of the key independent variables;

$\checkmark$ The substitution of the dependent variables; and

$\checkmark$ Using temporal break of the post-1980 period.

\subsection{Substitution of the key independent variables}

For the data shown in Appendix Table A.2, we use the System GMM in order to further test the results. We examine whether the baseline results hold when two alternative measures of oil wealth are employed as a proxy for oil wealth. The first one is the log of oil value (the quantity of oil and gas extracted in a given year multiplied by the per-unit world 

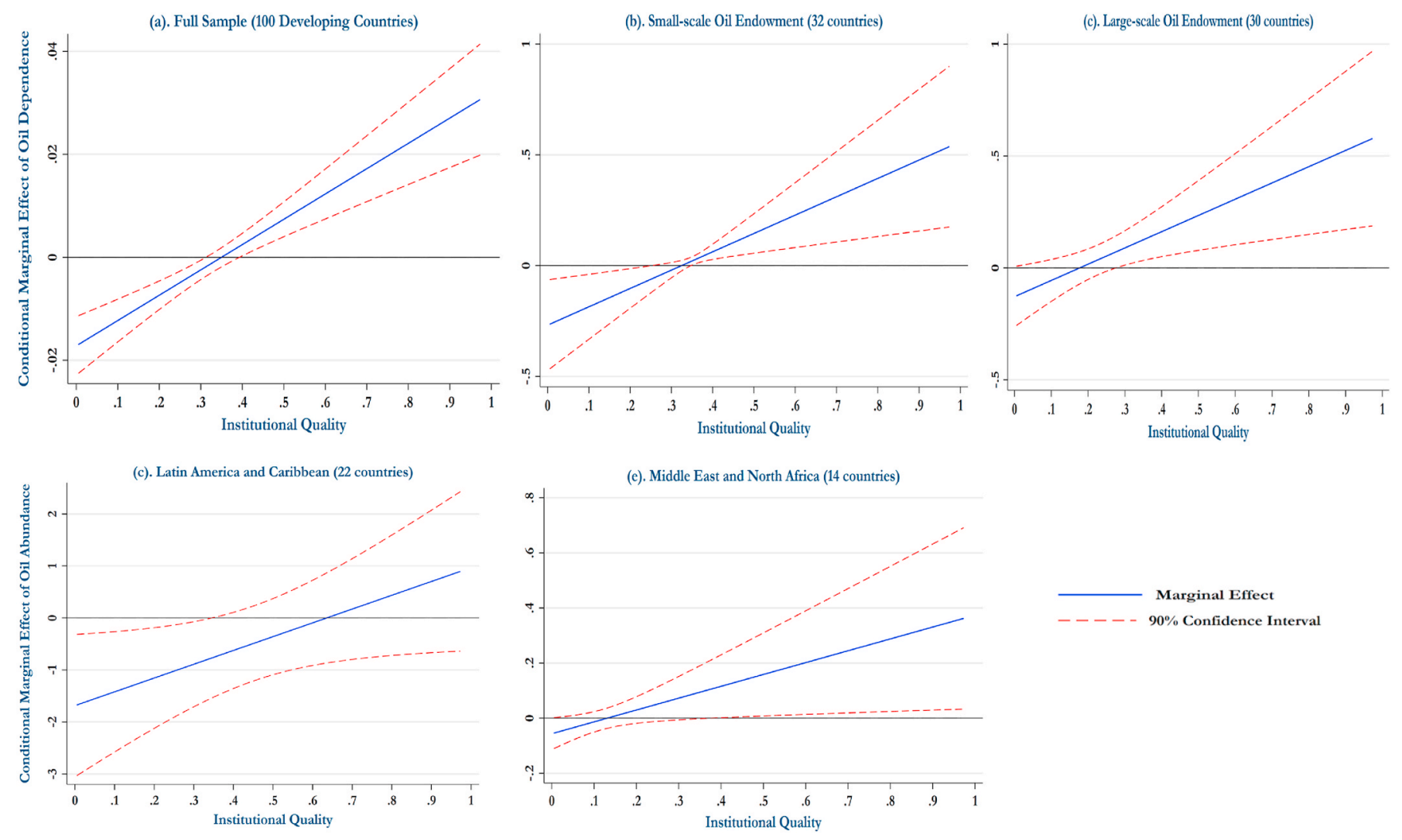

Note: Data are marginal effects based on the System GMM regression presented in Column 1 of Table 7. The 90 percent confidence intervals around the estimates are calculated using the Esarey and Sumner's (2017) procedure.

Fig. 5. Conditional marginal effect of oil dependence on democracy at different of levels of institutional quality (CMEoil dependence)

Note: Data are marginal effects based on the System GMM regression presented in Column 1 of Table 7 . The 90 percent confidence intervals around the estimates are calculated using the Esarey and Sumner's (2017) procedure.

price) from the dataset constructed by Ross and Mahdavi (2015); the second is the log of oil income as a share of GDP from the dataset constructed by Haber and Menaldo (2011). The results for the alternative measures of oil abundance are shown in the first five Columns. While the results for the alternative measure of oil dependence are reported in the last five Columns. Reassuringly, as we can also see in Table A.2, the effects of the alternative indicator of oil abundance and oil dependence on each of the five democracy measures in the full sample and for each of the country groups are consistent with our baseline estimations - with only a couple of exceptions. One of these is found in Panel A, Column 10: the negative effect of dependence on egalitarian democracy in the full sample has vanished and become insignificant, but the negative signs remain.

\subsection{Substitution of the dependent variables}

In Appendix Table A3, we replace the dependent variable with an alternative indicator of democracy. In Table A3, democratic institutions are measured by the Polity index, which is the most frequently used measure. On the one hand, the effects of oil abundance and oil dependence on the alternative measure of democracy (POLITY) in the full sample and for each of the country groups (Table A3) are consistent with our baseline estimations when we consider electoral democracy (Tables 1-5, Column 1). On the other hand, when we consider the baseline estimations of liberal democracy (Tables 1-5, Column 2), the estimates for POLITY have changed. This is not surprising because as we discussed above, POLITY does not capture the nuances of democracy that go beyond the multi-party electoral process.

\subsection{Temporal break (Post-1980 period)}

Some studies have argued that the effects of oil wealth on political institutions should have differed over time and only appeared post-1973 period (Haber and Menaldo, 2011), when oil prices experienced a significant increase that drove the oil-exporting countries to nationalize the assets of foreign-owned oil companies in the 1980s. Andersen and Ross (2013) argued that petroleum wealth's impact on democracy becomes negative in the post-break period after the second oil shock (post-1980). Based on these studies, we have chosen the post-1980 period as a temporal break to check whether our main results will hold or not. We add an interaction term between oil wealth measures (abundance/dependence) and a post-1980 dummy variable, which takes the value 0 for the years 1935 to 1980 and 1 for the years 1981-2014.

Appendix Table (A.4) present the System GMM estimation results in order to examine whether the post-1980 period drove our baseline results. Reassuringly, as we can also see in Columns 1-10 of Table A4, the effects of the term interacting oil abundance and oil dependence with the post- 1980 period on each of the five democracy measures in the full sample and for each of the country groups did not undergo any substantial change in the main results as reported in Tables $1-5$, with but a couple of exceptions. For instance, the insignificant negative effect of oil dependence on deliberative democracy in large oil endowed countries becomes statistically significant at $1 \%$ level with a negative sign in the post-1980 period. 


\section{Conclusion}

In this paper we have attempted to re-examine the oil and democracy nexus, which is central to the political resource curse by applying the latest democracy dataset, VDEM, into the analysis. This data source improves upon the shortcomings of previous data sets and allows us to delineate between different aspects of democracy. It allows us to specially separate the electoral process from the liberal aspect of respect for rights and rules. The existence or otherwise of the political resource curse is still far from resolved, with some studies indicating its presence, others its absence, and still others pointing to conditioning mechanisms. Our study is a contribution to this taxonomic literature where we improve on previous studies not only by employing a novel democratic data source, but also because we use two definitions of oil wealth which renders our results more robust, besides delineating the sample into small and large oil endowments and looking into the experience of two regions, Latin America and the Middle East. We also utilize dynamic panel data methods, which allows us to control for endogeneity issues.

Our results indicate that there is prima facie evidence for a political resource curse if we do not control for pre-existing institutions that promote democracy. This finding is true in the full sample of both oil abundant countries, as well as for nations whose economies are dependent on oil for generating national income. But once we decompose the sample into small and large oil endowments, the statistical significance of these results almost disappears, and also for Latin America. But the political resource curse still remains statistically significant for oil dependent economies in the Middle East and North Africa.

Above all, as hypothesized by us, we find strong evidence for support of the conditionalist view in the political resource curse literature pioneered by Dunning (2008). Once we control for pre-existing institutional quality, measured in our case by the rule of law, the political resource curse seems not to exist. In particular, we find that the interaction between the rule of law and our definitions of oil wealth promote democracy significantly, especially for electoral democracy. The rule of law is a powerful check on autocracy and autocratic practices. We also calculate threshold levels for the quality of the rule of law to be at in society before they turn a curse into a blessing. The converse is equally true, a deterioration in the quality and pervasiveness of the rule of law will cause the political resource curse to reappear, and democratic quality will decline.

Two other points are noteworthy. The first is to do with the various aspects of democracy captured by the V-DEM data. It appears that the most significant relationships between oil wealth and democracy lie in the sphere of electoral democracy. This may be because democracy is quite new to most developing countries, and is feature of the post-Cold War wave of democratization. The liberal aspects of democracy could be at an earlier stage of development. Secondly, the proposition that oil wealth hinders democracy varies across regions as indicated in our hypotheses, and is most true of the Middle Eastern and North African region, and this is in conformity with the stylized facts that suggest the prevalence of long-standing autocracies and absolute monarchies in that region.

\section{Authors statement}

We the undersigned declare that this manuscript is original, has not been published before and is not currently being considered for publication elsewhere.

We confirm that the manuscript has been read and approved by all named authors and that there are no other persons who satisfied the criteria for authorship but are not listed. We further confirm that the order of authors listed in the manuscript has been approved by all of us.

We understand that the Corresponding Author is the sole contact for the Editorial process. Brahim Bergougui is responsible for communicating with the other authors about progress, submissions of revisions and final approval of proofs.

\section{Acknowledgements}

We would like to thank the participants in The 4th conferences of the International Workshop on The Political Economy of Democracy and Dictatorship (The 4th PEDD) held in Münster, February 27 - 29, 2020. We are especially grateful to the editor and three referees of Resource Policy journal for their excellent comments and suggestions that have improved the paper.

\section{Appendix A. Supplementary data}

Supplementary data to this article can be found online at https://doi.org/10.1016/j.resourpol.2020.101905.

Annex A.

Table A.1

Descriptive Statistics

\begin{tabular}{|c|c|c|c|c|c|c|c|c|c|c|}
\hline \multirow{3}{*}{ Variable by Panel } & \multicolumn{10}{|c|}{ Country by Group } \\
\hline & \multicolumn{2}{|c|}{ Full sample (1) } & \multicolumn{2}{|c|}{ Small oil (2) } & \multicolumn{2}{|c|}{ Large oil (3) } & \multicolumn{2}{|c|}{ LAC (4) } & \multicolumn{2}{|c|}{ MENA (5) } \\
\hline & Mean & s. d & Mean & s. d & Mean & s. d & Mean & s. d & Mean & s. d \\
\hline \multicolumn{11}{|l|}{ Panel A. key Independent Variables } \\
\hline Oil value per capita (ln) 1935 & 2.46 & 2.08 & 0.11 & 0.19 & 3.66 & 1.38 & 3.95 & 1.49 & 3.43 & 3.59 \\
\hline Oil value per capita (ln) 2014 & 2.94 & 3.13 & 3.00 & 1.88 & 6.81 & 1.66 & 3.31 & 3.33 & 5.65 & 3.35 \\
\hline Oil value per capita (ln) $1935-2014$ & 2.30 & 2.85 & 1.86 & 1.74 & 5.20 & 2.74 & 2.83 & 2.81 & 5.01 & 3.50 \\
\hline Oil Value as \% of GDP 1935 & 0.11 & 0.26 & 0.00 & 0.00 & 0.14 & 0.29 & 0.22 & 0.38 & 0.04 & 0.09 \\
\hline Oil Value as \% of GDP 2014 & 0.18 & 0.53 & 0.16 & 0.41 & 0.45 & 0.82 & 0.13 & 0.36 & 0.19 & 0.26 \\
\hline Oil Value as \% of GDP $1935-2014$ & 0.16 & 0.59 & 0.14 & 0.69 & 0.37 & 0.71 & 0.12 & 0.36 & 0.25 & 0.40 \\
\hline \multicolumn{11}{|l|}{ Panel B. Dependent Variables } \\
\hline Electoral democracy 1935 & 0.11 & 0.10 & 0.12 & 0.09 & 0.09 & 0.08 & 0.21 & 0.11 & 0.12 & 0.12 \\
\hline Electoral democracy 2014 & 0.49 & 0.22 & 0.53 & 0.22 & 0.43 & 0.22 & 0.65 & 0.20 & 0.31 & 0.19 \\
\hline Electoral democracy 1935-2014 & 0.27 & 0.23 & 0.29 & 0.23 & 0.25 & 0.22 & 0.41 & 0.26 & 0.16 & 0.15 \\
\hline Liberal democracy 1935 & 0.28 & 0.20 & 0.26 & 0.19 & 0.30 & 0.24 & 0.31 & 0.25 & 0.36 & 0.22 \\
\hline \multirow[t]{2}{*}{ Liberal democracy 2014} & 0.55 & 0.28 & 0.60 & 0.29 & 0.49 & 0.28 & 0.58 & 0.31 & 0.56 & 0.26 \\
\hline & & & & & & & & & \multicolumn{2}{|c|}{ (continued on next page) } \\
\hline
\end{tabular}


Table A.1 (continued)

\begin{tabular}{|c|c|c|c|c|c|c|c|c|c|c|}
\hline \multirow{3}{*}{ Variable by Panel } & \multicolumn{10}{|c|}{ Country by Group } \\
\hline & \multicolumn{2}{|c|}{ Full sample (1) } & \multicolumn{2}{|c|}{ Small oil (2) } & \multicolumn{2}{|c|}{ Large oil (3) } & \multicolumn{2}{|c|}{ LAC (4) } & \multicolumn{2}{|c|}{ MENA (5) } \\
\hline & Mean & s. d & Mean & s. d & Mean & s. d & Mean & s. d & Mean & s. d \\
\hline Liberal democracy 1935-2014 & 0.36 & 0.27 & 0.36 & 0.28 & 0.35 & 0.26 & 0.41 & 0.30 & 0.39 & 0.24 \\
\hline Participatory democracy 1935 & 0.06 & 0.06 & 0.06 & 0.06 & 0.05 & 0.05 & 0.11 & 0.07 & 0.05 & 0.03 \\
\hline Participatory democracy 2014 & 0.30 & 0.16 & 0.33 & 0.16 & 0.26 & 0.17 & 0.43 & 0.16 & 0.17 & 0.11 \\
\hline Participatory democracy 1935-2014 & 0.15 & 0.15 & 0.16 & 0.16 & 0.14 & 0.14 & 0.25 & 0.18 & 0.08 & 0.08 \\
\hline Deliberative democracy 1935 & 0.07 & 0.08 & 0.08 & 0.07 & 0.06 & 0.06 & 0.12 & 0.11 & 0.09 & 0.08 \\
\hline Deliberative democracy 2014 & 0.37 & 0.20 & 0.43 & 0.20 & 0.31 & 0.20 & 0.51 & 0.22 & 0.23 & 0.16 \\
\hline Deliberative democracy $1935-2014$ & 0.19 & 0.20 & 0.21 & 0.21 & 0.16 & 0.18 & 0.29 & 0.24 & 0.12 & 0.11 \\
\hline Egalitarian democracy 1935 & 0.07 & 0.06 & 0.08 & 0.06 & 0.06 & 0.04 & 0.09 & 0.09 & 0.09 & 0.07 \\
\hline Egalitarian democracy 2014 & 0.33 & 0.18 & 0.38 & 0.19 & 0.28 & 0.18 & 0.44 & 0.20 & 0.21 & 0.13 \\
\hline Egalitarian democracy 1935-2014 & 0.19 & 0.16 & 0.21 & 0.17 & 0.17 & 0.15 & 0.26 & 0.21 & 0.14 & 0.09 \\
\hline \multicolumn{11}{|l|}{ Panel C. Other Independent Variables } \\
\hline GDP per capita $(\ln )$ & 7.91 & 0.86 & 7.83 & 0.91 & 8.49 & 1.30 & 8.32 & 0.72 & 8.83 & 1.47 \\
\hline Population (ln) & 15.63 & 1.49 & 15.95 & 1.63 & 16.04 & 1.83 & 15.64 & 1.57 & 15.28 & 1.86 \\
\hline Rule of law & 0.43 & 0.27 & 0.47 & 0.21 & 0.36 & 0.22 & 0.45 & 0.29 & 0.36 & 0.18 \\
\hline Number of countries & 100 & & 32 & & 30 & & 14 & & 22 & \\
\hline
\end{tabular}

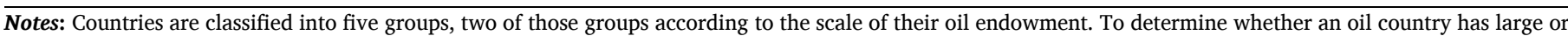

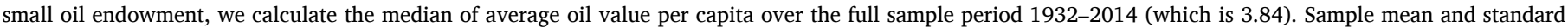
deviation are reported for each variable.

Table A.2

Oil Wealth and Democracy: Alternative Measures of Oil Abundance and Oil dependence.

\begin{tabular}{|c|c|c|c|c|c|c|c|c|c|c|}
\hline \multirow{3}{*}{$\begin{array}{l}\text { Dependent } \\
\text { Variables }\end{array}$} & \multicolumn{5}{|c|}{ Oil Abundance (Oil Value) } & \multicolumn{5}{|c|}{ Oil Dependence (Oil Income as a share of GDP from HM) } \\
\hline & \multirow{2}{*}{$\begin{array}{l}\text { Electoral } \\
\text { Democracy } \\
(1)\end{array}$} & \multirow{2}{*}{$\begin{array}{l}\text { Liberal } \\
\text { Democracy } \\
(2)\end{array}$} & \multirow{2}{*}{$\begin{array}{l}\text { Deliberative } \\
\text { Democracy } \\
(3)\end{array}$} & \multirow{2}{*}{$\begin{array}{l}\text { Participatory } \\
\text { Democracy } \\
(4)\end{array}$} & \multirow{2}{*}{$\begin{array}{l}\text { Egalitarian } \\
\text { Democracy }\end{array}$} & \multirow{2}{*}{$\begin{array}{l}\text { Electoral } \\
\text { Democracy } \\
(6)\end{array}$} & \multirow{2}{*}{$\begin{array}{l}\begin{array}{l}\text { Liberal } \\
\text { Democracy }\end{array} \\
(7)\end{array}$} & \multirow{2}{*}{$\begin{array}{l}\text { Deliberative } \\
\text { Democracy } \\
(8)\end{array}$} & \multirow{2}{*}{$\begin{array}{l}\text { Participatory } \\
\text { Democracy } \\
(9)\end{array}$} & \multirow{2}{*}{$\begin{array}{l}\text { Egalitarian } \\
\text { Democracy } \\
(10)\end{array}$} \\
\hline & & & & & & & & & & \\
\hline \multicolumn{11}{|c|}{ Panel (A). Full sample (100 countries) } \\
\hline \multirow{2}{*}{$\begin{array}{l}\text { Oil Abundance } \\
(\mathrm{t}-1)\end{array}$} & $-0.0005^{* * *}$ & $-0.0008^{* * *}$ & $-0.0004^{* * *}$ & $-0.0006^{* * *}$ & $-0.0004^{* * *}$ & / & / & / & / & / \\
\hline & $(0.0001)$ & $(0.0003)$ & $(0.0001)$ & $(0.0001)$ & $(0.0001)$ & / & / & / & / & / \\
\hline \multirow{2}{*}{$\begin{array}{l}\text { Oil } \\
\text { dependence } \\
\text { (t-1) }\end{array}$} & / & / & / & / & / & $-0.139 *$ & $-0.118^{* * *}$ & $-0.095^{*}$ & $-0.136^{*}$ & -0.070 \\
\hline & / & / & / & / & / & $(0.073)$ & $(0.020)$ & $(0.054)$ & $(0.076)$ & $(0.050)$ \\
\hline \multirow{2}{*}{$\begin{array}{l}\text { GDP per capita } \\
\text { (t-1) }\end{array}$} & $0.0042^{* *}$ & $0.0108^{* * *}$ & $0.0063^{* * *}$ & $0.0075^{* * *}$ & $0.0068 * * *$ & $0.011 *$ & $0.015^{* * *}$ & $0.009 * *$ & $0.011 *$ & 0.008 \\
\hline & $(0.0020)$ & $(0.0026)$ & $(0.0013)$ & $(0.0018)$ & $(0.0012)$ & $(0.006)$ & $(0.002)$ & $(0.004)$ & $(0.006)$ & $(0.005)$ \\
\hline \multirow{2}{*}{$\begin{array}{l}\text { Population } \\
\text { (t-1) }\end{array}$} & $0.0045^{* * *}$ & $0.0080 * * *$ & $0.0038^{* * *}$ & $0.0044 * * *$ & $0.0024 * * *$ & 0.003 & $0.005^{* * *}$ & $0.003^{*}$ & 0.003 & 0.002 \\
\hline & $(0.0009)$ & $(0.0016)$ & $(0.0005)$ & $(0.0006)$ & $(0.0005)$ & $(0.002)$ & $(0.001)$ & $(0.002)$ & $(0.002)$ & $(0.001)$ \\
\hline Observations & 790 & 790 & 790 & 790 & 790 & 827 & 827 & 827 & 827 & 827 \\
\hline $\begin{array}{l}\text { No. of } \\
\text { countries }\end{array}$ & 100 & 100 & 100 & 100 & 100 & 100 & 100 & 100 & 100 & 100 \\
\hline $\begin{array}{l}\text { Hansen J: } \\
\text { P-value }\end{array}$ & 0.0837 & 0.414 & 0.131 & 0.139 & 0.145 & 0.996 & 0.999 & 0.995 & 0.995 & 0.997 \\
\hline $\begin{array}{l}\text { AR (2): } \\
\text { P-value }\end{array}$ & 0.117 & 0.754 & 0.180 & 0.310 & 0.0827 & 0.0593 & 0.376 & 0.109 & 0.230 & 0.0479 \\
\hline \multicolumn{11}{|c|}{ Panel (B). Small-Scall oil endowment (32 countries) } \\
\hline \multirow{2}{*}{$\begin{array}{l}\text { Oil Abundance } \\
\text { (t-1) }\end{array}$} & -0.0759 & -0.0518 & -0.0699 & -0.0722 & -0.0603 & / & / & / & / & / \\
\hline & $(0.0668)$ & $(0.0984)$ & $(0.0471)$ & $(0.0603)$ & $(0.0493)$ & / & / & / & / & / \\
\hline \multirow{2}{*}{$\begin{array}{l}\text { Oil dependence } \\
\quad(\mathrm{t}-1)\end{array}$} & / & / & / & / & / & 3.944 & 0.908 & -0.698 & -0.057 & 0.039 \\
\hline & / & / & / & / & / & $(10.694)$ & (4.209) & $(0.715)$ & $(0.409)$ & $(0.354)$ \\
\hline \multirow{2}{*}{$\begin{array}{l}\text { GDP per capita } \\
\text { (t-1) }\end{array}$} & $1.3023^{*}$ & 1.1386 & 0.6276 & 0.6463 & $1.2463^{* *}$ & 0.031 & 0.002 & -0.024 & 0.003 & 0.018 \\
\hline & $(0.6778)$ & $(0.9086)$ & $(0.5676)$ & $(0.6840)$ & $(0.5854)$ & $(0.067)$ & $(0.018)$ & (.) & $(0.009)$ & $(0.016)$ \\
\hline \multirow{2}{*}{$\begin{array}{l}\text { Population } \\
\text { (t-1) }\end{array}$} & $0.5574 * *$ & $0.5485^{*}$ & $0.3824 * * *$ & 0.3598 & 0.2745 & 0.009 & 0.007 & 0.080 & 0.002 & 0.004 \\
\hline & $(0.2448)$ & $(0.3152)$ & $(0.1405)$ & $(0.2192)$ & $(0.2003)$ & $(0.030)$ & $(0.008)$ & $(0.089)$ & $(0.004)$ & $(0.006)$ \\
\hline Observations & 321 & 321 & 321 & 321 & 321 & 346 & 346 & 377 & 377 & 377 \\
\hline $\begin{array}{l}\text { No. of } \\
\text { countries }\end{array}$ & 32 & 32 & 32 & 32 & 32 & 32 & 32 & 32 & 32 & 32 \\
\hline $\begin{array}{l}\text { Hansen J: } \\
\text { P-value }\end{array}$ & 0.945 & 0.661 & 0.673 & 0.881 & 0.533 & 1 & 1 & 1 & 1 & 0.0757 \\
\hline $\begin{array}{l}\text { AR (2): } \\
\text { P-value }\end{array}$ & 0.267 & 0.220 & 0.760 & 0.889 & 0.0447 & 0.330 & 0.296 & 0.420 & 0.968 & 0.0702 \\
\hline \multicolumn{11}{|c|}{ Panel (C). Large-Scall oil endowment (30 countries) } \\
\hline & 0.0341 & 0.2290 & 0.0379 & 0.0228 & 0.0227 & / & / & / & / & / \\
\hline
\end{tabular}


Table A.2 (continued)

\begin{tabular}{|c|c|c|c|c|c|c|c|c|c|c|}
\hline \multirow{3}{*}{$\begin{array}{l}\text { Dependent } \\
\text { Variables }\end{array}$} & \multicolumn{5}{|c|}{ Oil Abundance (Oil Value) } & \multicolumn{5}{|c|}{ Oil Dependence (Oil Income as a share of GDP from HM) } \\
\hline & \multirow{2}{*}{$\begin{array}{l}\text { Electoral } \\
\text { Democracy }\end{array}$} & \multirow{2}{*}{$\begin{array}{l}\text { Liberal } \\
\text { Democracy } \\
(2)\end{array}$} & \multirow{2}{*}{$\begin{array}{l}\text { Deliberative } \\
\text { Democracy } \\
(3)\end{array}$} & \multirow{2}{*}{$\begin{array}{l}\text { Participatory } \\
\text { Democracy } \\
(4)\end{array}$} & \multirow{2}{*}{$\begin{array}{l}\text { Egalitarian } \\
\text { Democracy }\end{array}$} & \multirow{2}{*}{$\begin{array}{l}\text { Electoral } \\
\text { Democracy } \\
(6)\end{array}$} & \multirow{2}{*}{$\begin{array}{l}\begin{array}{l}\text { Liberal } \\
\text { Democracy }\end{array} \\
(7)\end{array}$} & \multirow{2}{*}{$\begin{array}{l}\text { Deliberative } \\
\text { Democracy } \\
(8)\end{array}$} & \multirow{2}{*}{$\begin{array}{l}\text { Participatory } \\
\text { Democracy } \\
(9)\end{array}$} & \multirow{2}{*}{$\begin{array}{l}\text { Egalitarian } \\
\text { Democracy } \\
(10)\end{array}$} \\
\hline & & & & & & & & & & \\
\hline \multicolumn{11}{|l|}{$\begin{array}{l}\text { Oil Abundance } \\
\text { (t-1) }\end{array}$} \\
\hline & $(0.0786)$ & $(0.1733)$ & $(0.0404)$ & $(0.0631)$ & $(0.0287)$ & / & / & / & / & / \\
\hline \multirow{2}{*}{$\begin{array}{l}\text { Oil dependence } \\
\text { (t-1) }\end{array}$} & / & / & / & / & / & -0.0929 & 0.472 & -0.011 & 0.147 & -0.008 \\
\hline & / & / & / & / & / & $(0.0670)$ & $(0.861)$ & $(0.032)$ & $(0.164)$ & $(0.024)$ \\
\hline \multirow{2}{*}{$\begin{array}{l}\text { GDP per capita } \\
(\mathrm{t}-1)\end{array}$} & -0.3637 & -0.4644 & -0.2780 & 0.0613 & 0.0484 & 0.0115 & -0.055 & 0.004 & -0.047 & 0.004 \\
\hline & $(0.5325)$ & $(1.4196)$ & $(0.4065)$ & $(0.5731)$ & $(0.2848)$ & $(0.0135)$ & $(0.130)$ & $(0.005)$ & $(0.042)$ & $(0.005)$ \\
\hline \multirow{2}{*}{$\begin{array}{l}\text { Population } \\
\text { (t-1) }\end{array}$} & 0.2188 & -0.0989 & 0.1670 & 0.2897 & 0.1248 & 0.0071 & -0.009 & $0.003^{* *}$ & 0.002 & $0.003^{*}$ \\
\hline & $(0.3918)$ & $(0.5236)$ & $(0.2226)$ & $(0.3474)$ & $(0.1840)$ & $(0.0068)$ & $(0.022)$ & $(0.001)$ & $(0.003)$ & $(0.002)$ \\
\hline Observations & 349 & 349 & 349 & 349 & 349 & 355 & 355 & 355 & 355 & 355 \\
\hline $\begin{array}{l}\text { No. of } \\
\text { countries }\end{array}$ & 30 & 30 & 30 & 30 & 30 & 30 & 30 & 30 & 30 & 30 \\
\hline $\begin{array}{l}\text { Hansen J: } \\
\text { P-value }\end{array}$ & 0.157 & 0.0521 & 0.0523 & 0.236 & 0.400 & 0.609 & 1 & 1 & 1 & 1 \\
\hline AR (2): P-value & 0.217 & 0.226 & 0.0865 & 0.143 & 0.384 & 0.183 & 0.749 & 0.105 & 0.213 & 0.405 \\
\hline \multicolumn{11}{|c|}{ Panel (D). Latin America and the Caribbean (22 countries) } \\
\hline \multirow{2}{*}{$\begin{array}{l}\text { Oil Abundance } \\
\text { (t-1) }\end{array}$} & -0.1611 & 0.0372 & -0.0269 & -0.0657 & -0.1033 & / & / & / & / & / \\
\hline & $(0.1381)$ & $(0.2762)$ & $(0.0557)$ & $(0.0844)$ & $(0.1517)$ & / & / & / & / & / \\
\hline \multirow{2}{*}{$\begin{array}{l}\text { Oil dependence } \\
\quad(\mathrm{t}-1)\end{array}$} & / & / & / & / & / & -2.601 & 0.055 & 0.047 & 2.521 & 1.708 \\
\hline & / & / & / & / & / & $(4.597)$ & $(0.143)$ & $(0.117)$ & $(5.067)$ & (1.140) \\
\hline \multirow{2}{*}{$\begin{array}{l}\text { GDP per capita } \\
(\mathrm{t}-1)\end{array}$} & $8.5468^{* *}$ & -2.0919 & 0.8001 & 3.6101 & 6.2069 & 0.054 & 0.032 & 0.187 & 0.096 & -0.019 \\
\hline & $(3.3410)$ & (8.0964) & $(3.8320)$ & (.) & (4.5795) & $(0.087)$ & $(0.027)$ & $(0.407)$ & $(0.918)$ & $(0.233)$ \\
\hline \multirow{2}{*}{$\begin{array}{l}\text { Population } \\
\text { (t-1) }\end{array}$} & 1.3075 & -1.2500 & 0.0388 & 0.1958 & 0.3137 & 0.016 & 0.004 & 0.050 & 0.333 & 0.008 \\
\hline & $(1.2465)$ & $(2.6124)$ & $(0.3215)$ & $(0.4484)$ & (1.1413) & $(0.017)$ & $(0.003)$ & $(0.144)$ & $(0.375)$ & $(0.035)$ \\
\hline Observations & 246 & 246 & 246 & 246 & 246 & 298 & 298 & 298 & 298 & 298 \\
\hline $\begin{array}{l}\text { No. of } \\
\text { countries }\end{array}$ & 22 & 22 & 22 & 22 & 22 & 22 & 22 & 22 & 22 & 22 \\
\hline $\begin{array}{l}\text { Hansen J: } \\
\text { P-value }\end{array}$ & 0.938 & 0.999 & 0.617 & 0.384 & 0.362 & 0.892 & 0.387 & 1 & 1 & 1 \\
\hline $\begin{array}{l}\text { AR (2): } \\
\text { P-value }\end{array}$ & 0.154 & 0.813 & 0.436 & 0.926 & 0.556 & 0.120 & 0.125 & 0.805 & 0.448 & 0.764 \\
\hline \multirow{3}{*}{$\begin{array}{l}\text { Panel (E). Middle } \\
\text { Oil Abundance } \\
\quad(\mathrm{t}-1)\end{array}$} & Eastern and & rth African (1 & countries) & & & & & & & \\
\hline & -0.0396 & 0.0513 & -0.0815 & -0.1408 & $-0.1017^{* *}$ & / & / & / & / & / \\
\hline & $(0.1539)$ & $(0.0876)$ & $(0.0696)$ & $(0.1322)$ & $(0.0468)$ & 1 & / & / & / & / \\
\hline Oil dependence & / & / & / & / & / & $-0.433^{* * *}$ & -0.147 & -0.024 & $-0.359^{* * *}$ & $-0.198^{* * *}$ \\
\hline & / & / & / & / & / & $(0.090)$ & $(0.121)$ & $(0.028)$ & (0.119) & $(0.028)$ \\
\hline GDP per capita & 0.6483 & -0.1046 & 1.5611 & 3.6456 & 0.9106 & 0.039 & 0.033 & 0.002 & 0.027 & $0.039^{* *}$ \\
\hline & $(1.2915)$ & (1.8045) & (1.0117) & $(3.1142)$ & $(1.0085)$ & $(0.030)$ & $(0.024)$ & $(0.003)$ & $(0.021)$ & $(0.016)$ \\
\hline Population & 1.2789 & -0.8120 & $1.6220^{*}$ & $2.6961^{*}$ & 0.7306 & $0.005^{* * *}$ & 0.012 & $0.003^{* *}$ & 0.021 & $-0.003^{*}$ \\
\hline & (1.0454) & (1.8334) & $(0.9842)$ & (1.5847) & $(0.6133)$ & $(0.002)$ & $(0.012)$ & $(0.001)$ & $(0.020)$ & $(0.002)$ \\
\hline Observations & 148 & 148 & 148 & 148 & 148 & 163 & 163 & 163 & 163 & 163 \\
\hline $\begin{array}{l}\text { No. of } \\
\text { countries }\end{array}$ & 14 & 14 & 14 & 14 & 14 & 14 & 14 & 14 & 14 & 14 \\
\hline $\begin{array}{l}\text { Hansen J: } \\
\text { P-value }\end{array}$ & 1 & 1 & 1 & 1 & 1 & 1 & 1 & 0.915 & 1 & 1 \\
\hline $\begin{array}{l}\text { AR (2): } \\
\text { P-value }\end{array}$ & 0.856 & 0.368 & 0.0546 & 0.0262 & 0.371 & 0.366 & 0.631 & 0.265 & 0.453 & 0.717 \\
\hline
\end{tabular}

Note. All regressions are two-step system GMM. Two-step robust standard errors, which incorporated the Windmeijer (2005) correction, are in parentheses. *p $<0.10$, $* * \mathrm{p}<0.05, * * * \mathrm{p}<0.01$. AR (2) $=$ Arrelano-Bond test for second-order serial correlation. Hansen test $=$ Test of instrument over-identification restrictions. HM $=$ Haber Menaldo 2011 APSR Dataset.

Table A.3

Oil Wealth and Democracy: Alternative Measures of Democracy.

\begin{tabular}{|c|c|c|c|c|c|}
\hline \multirow{3}{*}{ Dependent Variable (POLITY) } & \multicolumn{5}{|c|}{ Panel (A). Oil Abundance (Oil Value per capita) and Democracy } \\
\hline & Full Sample & Small-Scall oil endowment & Large-Scall oil endowment & Latin America and the Caribbean & Middle Eastern and North African \\
\hline & (1) & (2) & (3) & (4) & (5) \\
\hline
\end{tabular}


Table A.3 (continued)

\begin{tabular}{|c|c|c|c|c|c|}
\hline \multirow{3}{*}{ Dependent Variable (POLITY) } & \multicolumn{5}{|c|}{ Panel (A). Oil Abundance (Oil Value per capita) and Democracy } \\
\hline & \multirow{2}{*}{$\frac{\text { Full Sample }}{(1)}$} & \multirow{2}{*}{$\frac{\text { Small-Scall oil endowment }}{(2)}$} & \multirow{2}{*}{$\frac{\text { Large-Scall oil endowment }}{(3)}$} & \multirow{2}{*}{$\frac{\text { Latin America and the Caribbean }}{\text { (4) }}$} & \multirow{2}{*}{$\frac{\text { Middle Eastern and North African }}{(5)}$} \\
\hline & & & & & \\
\hline Oil Abundance (t-1) & $\begin{array}{l}-0.103^{*} \\
(0.057)\end{array}$ & $\begin{array}{l}-0.241 \\
(0.277)\end{array}$ & $\begin{array}{l}0.175^{* *} \\
(0.0682)\end{array}$ & $\begin{array}{l}0.216 \\
(1.000)\end{array}$ & $\begin{array}{l}-0.377 \\
(0.411)\end{array}$ \\
\hline GDP per capita (t-1) & $\begin{array}{l}0.305^{* * *} \\
(0.064)\end{array}$ & $\begin{array}{l}1.350 \\
(1.811)\end{array}$ & $\begin{array}{l}-0.249^{*} \\
(0.151)\end{array}$ & $\begin{array}{l}-0.709 \\
(10.511)\end{array}$ & $\begin{array}{l}0.226 \\
(0.284)\end{array}$ \\
\hline Population (t-1) & $\begin{array}{l}0.131 \\
(0.119)\end{array}$ & $\begin{array}{l}0.755 \\
(1.085)\end{array}$ & $\begin{array}{l}-0.0173 \\
(0.0984)\end{array}$ & $\begin{array}{l}-0.734 \\
(2.080)\end{array}$ & $\begin{array}{l}-0.086 \\
(0.110)\end{array}$ \\
\hline Observations & 1,036 & 343 & 299 & 262 & 143 \\
\hline No. of countries & 100 & 32 & 30 & 22 & 14 \\
\hline Hansen J: P-value & 1 & 0.471 & 1 & 1 & 1 \\
\hline AR (2): P-value & 0.801 & 0.183 & 0.328 & 0.279 & 0.263 \\
\hline & Panel (B). $\mathrm{O}$ & Dependence (Oil Value as & share of GDP) and Democr & & \\
\hline Dependent Variable (POLITY) & $\begin{array}{l}\text { Full Sample } \\
\text { (1) }\end{array}$ & $\begin{array}{l}\text { Small-Scall oil endowment } \\
\text { (2) }\end{array}$ & $\begin{array}{l}\text { Large-Scall oil endowment } \\
\text { (3) }\end{array}$ & $\begin{array}{l}\text { Latin America and the Caribbean } \\
\text { (4) }\end{array}$ & $\begin{array}{l}\text { Middle Eastern and North African } \\
\text { (5) }\end{array}$ \\
\hline Oil Dependence (t-1) & $\begin{array}{l}-0.280^{* * *} \\
(0.070)\end{array}$ & $\begin{array}{l}0.455 \\
(0.582)\end{array}$ & $\begin{array}{l}-2.839 \\
(1.918)\end{array}$ & $\begin{array}{l}2.118 \\
(7.081)\end{array}$ & $\begin{array}{l}-1.345 \\
(18.122)\end{array}$ \\
\hline GDP per capita (t-1) & $\begin{array}{l}0.153^{* *} \\
(0.065)\end{array}$ & $\begin{array}{l}3.133 \\
(2.160)\end{array}$ & $\begin{array}{l}3.877 \\
(2.791)\end{array}$ & $\begin{array}{l}7.266 \\
(12.423)\end{array}$ & $\begin{array}{l}0.726 \\
(2.503)\end{array}$ \\
\hline Population (t-1) & $\begin{array}{l}0.095 * * \\
(0.043)\end{array}$ & $\begin{array}{l}1.826 \\
(1.306)\end{array}$ & $\begin{array}{l}12.798 \\
(8.675)\end{array}$ & $\begin{array}{l}1.632 \\
(2.789)\end{array}$ & $\begin{array}{l}0.057 \\
(1.585)\end{array}$ \\
\hline Observations & 1,032 & 341 & 291 & 241 & 128 \\
\hline No. of countries & 100 & 32 & 30 & 22 & 14 \\
\hline Hansen J: P-value & 1 & 0.602 & 1 & 0.999 & 1 \\
\hline AR (2): P-value & 0.315 & 0.732 & 0.735 & 0.482 & 0.769 \\
\hline
\end{tabular}

Note. All regressions are two-step system GMM. Two-step robust standard errors, which incorporated the Windmeijer (2005) correction, are in parentheses. *p $<0.10$, ${ }^{* *} \mathrm{p}<0.05,{ }^{* * *} \mathrm{p}<0.01$. AR (2) = Arrelano-Bond test for second-order serial correlation. Hansen test $=$ Test of instrument over-identification restrictions..

Table A.4

Oil Wealth and Democracy: Temporal break of post-1980 period

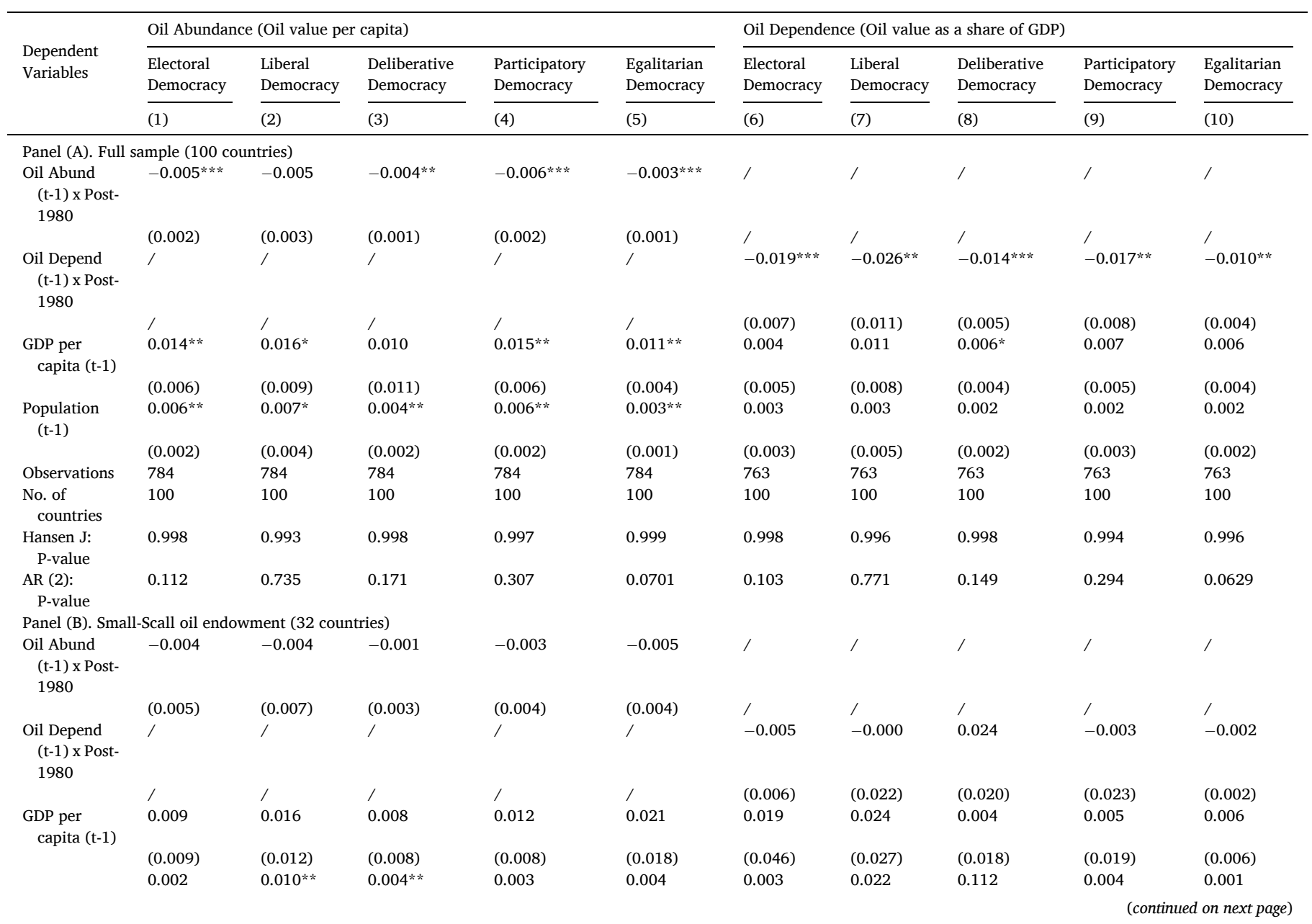


Table A.4 (continued)

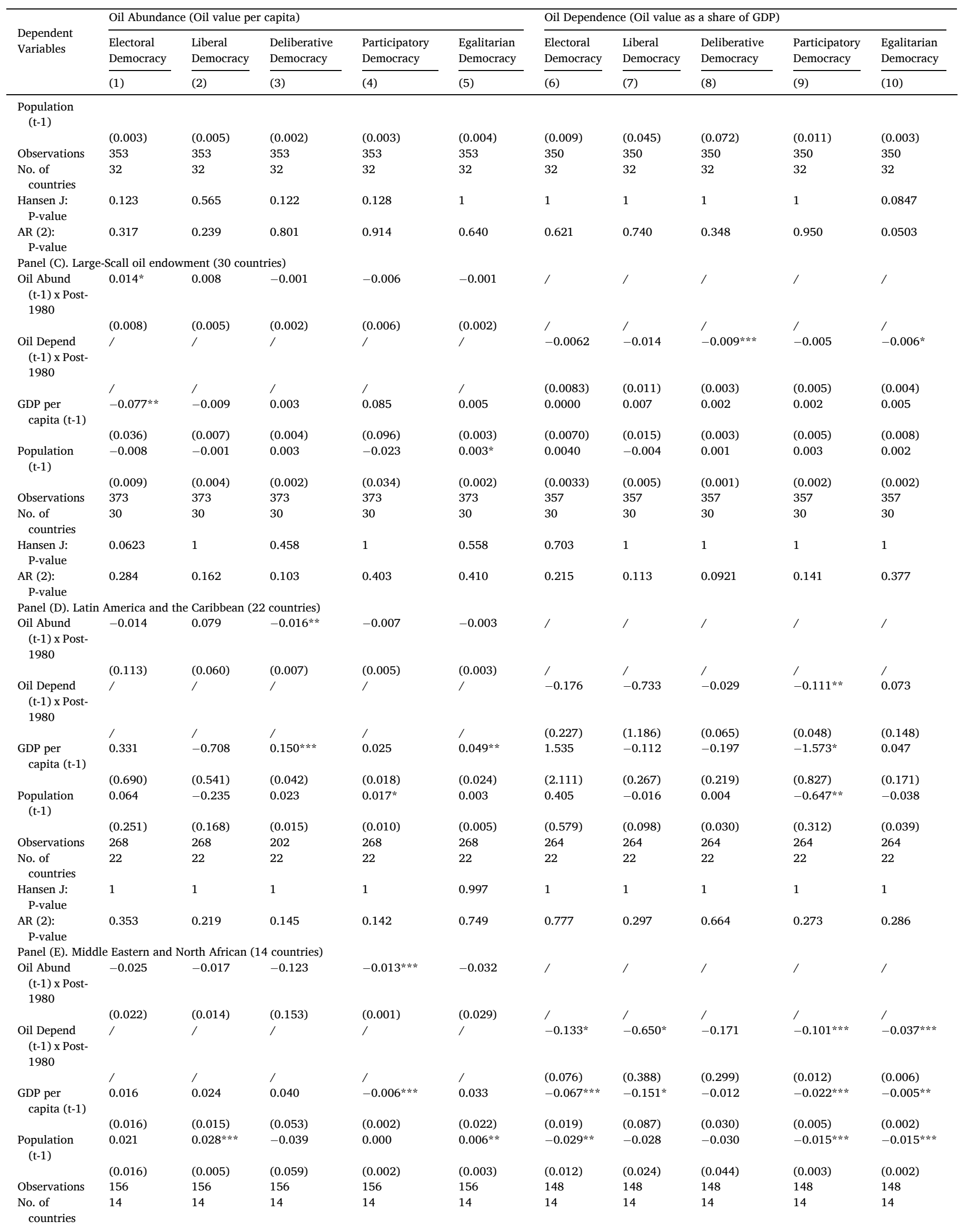


Table A.4 (continued)

\begin{tabular}{|c|c|c|c|c|c|c|c|c|c|c|}
\hline \multirow{3}{*}{$\begin{array}{l}\text { Dependent } \\
\text { Variables }\end{array}$} & \multicolumn{5}{|c|}{ Oil Abundance (Oil value per capita) } & \multicolumn{5}{|c|}{ Oil Dependence (Oil value as a share of GDP) } \\
\hline & $\begin{array}{l}\text { Electoral } \\
\text { Democracy }\end{array}$ & $\begin{array}{l}\text { Liberal } \\
\text { Democracy }\end{array}$ & $\begin{array}{l}\text { Deliberative } \\
\text { Democracy }\end{array}$ & $\begin{array}{l}\text { Participatory } \\
\text { Democracy }\end{array}$ & $\begin{array}{l}\text { Egalitarian } \\
\text { Democracy }\end{array}$ & $\begin{array}{l}\text { Electoral } \\
\text { Democracy }\end{array}$ & $\begin{array}{l}\text { Liberal } \\
\text { Democracy }\end{array}$ & $\begin{array}{l}\text { Deliberative } \\
\text { Democracy }\end{array}$ & $\begin{array}{l}\text { Participatory } \\
\text { Democracy }\end{array}$ & $\begin{array}{l}\text { Egalitarian } \\
\text { Democracy }\end{array}$ \\
\hline & (1) & (2) & (3) & (4) & (5) & (6) & (7) & (8) & (9) & (10) \\
\hline $\begin{array}{r}\text { Hansen J: } \\
\text { P-value }\end{array}$ & 1 & 1 & 1 & 1 & 1 & 1 & 1 & 1 & 1 & 1 \\
\hline $\begin{array}{l}\text { AR (2): } \\
\text { P-value }\end{array}$ & 0.512 & 0.626 & 0.489 & 0.0298 & 0.830 & 0.419 & 0.127 & 0.842 & 0.819 & 0.505 \\
\hline
\end{tabular}

Note. All regressions are two-step system GMM. Two-step robust standard errors, which incorporated the Windmeijer (2005) correction, are in parentheses. * $<<0.10$,

$* * \mathrm{p}<0.05,{ }^{* * *} \mathrm{p}<0.01$. AR(2) = Arrelano-Bond test for second-order serial correlation. Hansen test $=$ Test of instrument over-identification restrictions..

\section{References}

Acemoglu, D., Johnson, S., Robinson, J.A., 2001. The colonial origins of comparative development: an empirical investigation. Am. Econ. Rev. 91 (5), 1369-1401. https://doi.org/10.1257/aer.91.5.1369.

Ahmadov, A.K., 2013. Oil, democracy, and context: a meta-analysis. Comp. Polit. Stud. 47 (9), 1238-1267. https://doi.org/10.1177/0010414013495358.

Alexeev, M., Conrad, R., 2009. The elusive curse of oil. Rev. Econ. Stat. 91 (3), 586-598. https://doi.org/10.1162/rest.91.3.586.

Al-Ubaydli, O., 2012. Natural resources and the tradeoff between authoritarianism and development. J. Econ. Behav. Organ. 81 (1), 137-152. https://doi.org/10.1016/j. jebo.2011.09.009.

Andersen, J.J., Aslaksen, S., 2013. Oil and political survival. J. Dev. Econ. 100 (1), 89-106. https://doi.org/10.1016/j.jdeveco.2012.08.008.

Andersen, J.J., Ross, M.L., 2013. The big oil change: a closer look at the haber-menaldo analysis. Comp. Polit. Stud. 47 (7), 993-1021. https://doi.org/10.1177/ 0010414013488557.

Anyanwu, J.C., Erhijakpor, A.E.O., 2014. Does oil wealth affect democracy in Africa? Afr. Dev. Rev. 26 (1), 15-37. https://doi.org/10.1111/1467-8268.12061.

Arellano, M., Bover, O., 1995. Another look at the instrumental variable estimation of error-components models. J. Econom. 68 (1), 29-51. https://doi.org/10.1016/03044076(94)01642-D.

Aslaksen, S., 2010. Oil and democracy: more than a cross-country correlation? J. Peace Res. 47 (4), 421-431. https://doi.org/10.1177/0022343310368348.

Auty, R.M., 2001. The political economy of resource-driven growth. Eur. Econ. Rev. 45 (4), 839-846. https://doi.org/10.1016/S0014-2921(01)00126-X.

Aytaç, S.E., Mousseau, M., Örsün, Ö.F., 2016. Why some countries are immune from the resource curse: the role of economic norms. Democratization 23 (1), 71-92. https:// doi.org/10.1080/13510347.2014.964216.

Badeeb, R.A., Lean, H.H., Clark, J., 2017. The evolution of the natural resource curse thesis: a critical literature survey. Resour. Pol. 51, 123-134. https://doi.org/ 10.1016/j.resourpol.2016.10.015.

Bhavnani, R.R., Lupu, N., 2016. Oil Windfalls and the Political Resource Curse: Evidence from a Natural Experiment in Brazil. Unpublished Manuscript, University of Wisconsin.

Boese, V.A., 2019. How (not) to measure democracy. Int. Area Stud. Rev. 22 (2), 95-127. https://doi.org/10.1177/2233865918815571.

Bolt, J., van Zanden, J.L., 2014. The Maddison Project: collaborative research on historical national accounts. Econ. Hist. Rev. 67 (3), 627-651. https://doi.org/ 10.1111/1468-0289.12032.

Brooks, S.M., Kurtz, M.J., 2016. Oil and democracy: endogenous natural resources and the political "resource curse". Int. Organ. 70 (2), 279-311. https://doi.org/10.1017/ S0020818316000072.

Brückner, M., Ciccone, A., Tesei, A., 2011. Oil price shocks, income, and democracy. Rev. Econ. Stat. 94 (2), 389-399. https://doi.org/10.1162/REST_a_00201.

Brunnschweiler, C.N., Bulte, E.H., 2008. The resource curse revisited and revised: a tailof paradoxes and red herrings. J. Environ. Econ. Manag. 55, 248-264. https://doi.org/ 10.1016/j.jeem.2007.08.004.

Caselli, F., Tesei, A., 2015. Resource windfalls, political regimes, and political stability. Rev. Econ. Stat. 98 (3), 573-590. https://doi.org/10.1162/REST a 00538.

Cassidy, T., 2019. The long-run effects of oil wealth on development: evidence from petroleum geology. Econ. J. 129 (623), 2745-2778. https://doi.org/10.1093/ej/ uez009.

Coppedge, M., Lindberg, S., Skaaning, S.-E., Teorell, J., 2015. Measuring high level democratic principles using the V-Dem data. Int. Polit. Sci. Rev. 37 (5), 580-593. https://doi.org/10.1177/0192512115622046.

Cotet, A.M., Tsui, K.K., 2013. Oil and conflict: what does the cross country evidence really show? Am. Econ. J. Macroecon. 5 (1), 49-80. https://doi.org/10.1257/ mac.5.1.49.

Dunning, T., 2008. Crude Democracy: Natural Resource Wealth and Political Regimes. Cambridge University Press, Cambridge.

Elff, M., Ziaja, S., 2018. Method Factors in Democracy Indicators Politics and Governance 6 (1), 92-104. https://doi.org/10.17645/pag.v6i1.1235.

Esarey, J., Sumner, J.L., 2017. Marginal effects in interaction models: determining and controlling the false positive rate. Comp. Polit. Stud. 51 (9), 1144-1176. https://doi. org/10.1177/0010414017730080.

Fails, M.D., 2019. Fuel subsidies limit democratization: evidence from a global sample, 1990-2014. Int. Stud. Q. 63 (2), 354-363. https://doi.org/10.1093/isq/sqy061.
Frankel, J.A., 2010. The Natural Resource Curse: A Survey. National Bureau of Economic Research Working Paper Series. https://doi.org/10.3386/w15836. No. 15836.

Goldberg, E., Wibbels, E., Mvukiyehe, E., 2008. Lessons from strange cases: democracy, development, and the resource curse in the U.S. States. Comp. Polit. Stud. 41 (4-5), 477-514. https://doi.org/10.1177/0010414007313123.

Haber, S., Menaldo, V., 2011. Do natural resources fuel authoritarianism? A reappraisal of the resource curse. Am. Polit. Sci. Rev. 105 (1), 1-26. https://doi.org/10.1017/ S0003055410000584.

Hall, A.R., 2007. Generalized method of moments. In: Baltagi, B.H. (Ed.), A Companion to Theoretical Econometrics. https://doi.org/10.1002/9780470996249.ch12.

Hendrix, C.S., 2018. Cold war geopolitics and the making of the oil curse. J. Glob. Secur. Stud. 3 (1), 2-22. https://doi.org/10.1093/jogss/ogx022.

Herb, M., 2005. No representation without taxation? Rents, development, and democracy. Comp. Polit. 37 (3), 297-316. https://doi.org/10.2307/20072891.

Houle, C., 2018. A two-step theory and test of the oil curse: the conditional effect of oil on democratization. Democratization 25 (3), 404-421. https://doi.org/10.1080/ 13510347.2017.1366449.

James, A., 2019. Fata morganas in oil-rich, institution-poor economies. Resour. Pol. 60, 234-242. https://doi.org/10.1016/j.resourpol.2018.12.016.

Jensen, N., Wantchekon, L., 2004. Resource wealth and political regimes in Africa. Comp. Polit. Stud. 37 (7), 816-841. https://doi.org/10.1177/0010414004266867.

Jones Luong, P., Weinthal, E., 2010. Oil Is Not a Curse: Ownership Structure and Institutions in Soviet Successor States. Cambridge University Press, Cambridge.

Lall, R., 2016. The missing dimension of the political resource curse debate. Comp. Polit. Stud. 50 (10), 1291-1324. https://doi.org/10.1177/0010414016666861.

Lindberg, S.I., Coppedge, M., Gerring, J., Teorell, J., 2014. V-Dem: a new way to measure democracy. J. Democr. 25 (3), 159-169. https://doi.org/10.1353/jod.2014.0040.

Liou, Y.-M., Musgrave, P., 2013. Refining the oil curse: country-level evidence from exogenous variations in resource income. Comp. Polit. Stud. 47 (11), 1584-1610. https://doi.org/10.1177/0010414013512607.

Masi, T., Ricciuti, R., 2019. The heterogeneous effect of oil discoveries on democracy. Econ. Polit. 31 (3), 374-402. https://doi.org/10.1111/ecpo.12131.

Mehlum, H., Moene, K., Torvik, R., 2006. Institutions and the resource curse. Econ. J. 116 (508), 1-20. https://doi.org/10.1111/j.1468-0297.2006.01045.x.

Menaldo, V., 2016. The Institutions Curse: Natural Resources, Politics, and Development, Cambridge University Press, Cambridge.

Mitze, T., 2012. Dynamic simultaneous Equations with panel data: small sample properties and application to regional econometric modelling. In: Mitze, T. (Ed.), Empirical Modelling in Regional Science: towards a Global Time-Space-Structural Analysis. Springer Berlin Heidelberg, Berlin, Heidelberg, pp. 219-271.

Murshed, S.M., 2018. The Resource Curse. Columbia University Press, New York.

O'Connor, K.J., Blanco, L.R., Nugent, J.B., 2018. Does oil really curse democracy? A long-run time-series analysis of 127 countries. Resour. Pol. 57, 264-277. https://doi. org/10.1016/j.resourpol.2018.03.012.

Omgba, L.D., 2015. Why do some oil-producing countries succeed in democracy while others fail? World Dev. 76, 180-189. https://doi.org/10.1016/j. worlddev.2015.07.005.

Oskarsson, S., Ottosen, E., 2010. Does oil still hinder democracy? J. Dev. Stud. 46 (6), 1067-1083. https://doi.org/10.1080/00220380903151058.

Ramsay, K.W., 2011. Revisiting the resource curse: natural disasters, the price of oil, and democracy. Int. Organ. 65 (3), 507-529. https://doi.org/10.1017/ S002081831100018X.

Ross, M., Mahdavi, P., 2015. Oil and Gas Data, 1932-2014. https://doi.org/10.7910/ DVN/ZTPWOY. Retrieved from:

Ross, M., 2009. Oil and Democracy Revisited. Los Angeles. University of California, Los Angeles.

Ross, M.L., 2001. Does oil hinder democracy? World Polit. 53 (3), 325-361. https://doi. org/10.1353/wp.2001.0011.

Ross, M.L., 2015. What have we learned about the resource curse? Annu. Rev. Polit. Sci. 18 (1), 239-259. https://doi.org/10.1146/annurev-polisci-052213-040359.

Sachs, J.D., Warner, A.M., 1995. Natural Resource Abundance and Economic Growth. National Bureau of Economic Research Working Paper Series. https://doi.org/ 10.3386/w5398. No. 5398.

Smith, B., 2004. Oil wealth and regime survival in the developing world, 1960-1999. Am. J. Polit. Sci. 48 (2), 232-246. https://doi.org/10.1111/j.00925853.2004.00067.x. 
Tsui, K.K., 2011. More oil, less democracy: evidence from worldwide crude oil discoveries*. Econ. J. 121 (551), 89-115. https://doi.org/10.1111/j.14680297.2009.02327.x.

Ulfelder, J., 2007. Natural-resource wealth and the survival of autocracy. Comp. Polit. Stud. 40 (8), 995-1018. https://doi.org/10.1177/0010414006287238.

Wacziarg, R., 2012. The first law of petropolitics. Economica 79 (316), 641-657. https:// doi.org/10.1111/j.1468-0335.2011.00902.x.
Wiens, D., Poast, P., Clark, W.R., 2014. The political resource curse: an empirical Reevaluation. Polit. Res. Q. 67 (4), 783-794. Retrieved from. www.jstor.org/stable /24371951.

Wigley, S., 2018. Is there a resource curse for private liberties? Int. Stud. Q. 62 (4), 834-844. https://doi.org/10.1093/isq/sqy031.

Windmeijer, F., 2005. A finite sample correction for the variance of linear efficient twostep GMM estimators. J. Econom. 126 (1), 25-51. https://doi.org/10.1016/j. jeconom.2004.02.005. 